\title{
Moderating Effects of Media Coverage and Corporate Governance on CSR-CFP Nexus - Evidence from Listed Companies on Taiwan Stock Exchange
}

\author{
Yuan Chang ${ }^{1}$ \\ ${ }^{1}$ Department of Finance, National Changhua University of Education, Changhua, Taiwan (R.O.C) \\ Correspondence: Yuan Chang, Department of Finance, National Changhua University of Education. Address: No. \\ 2, Shi-Da Road, Changhua City, Taiwan (R.O.C). Tel: 886-47-232-105\#7350. E-mail: ychang@cc.ncue.edu.tw
}

Received: February 15, 2016

Accepted: March 9, 2016

Online Published: April 25, 2016

doi:10.5539/ijef.v8n5p190

URL: http://dx.doi.org/10.5539/ijef.v8n5p190

\begin{abstract}
Media coverage helps firm's benevolent action under the sunlight (well-known by the public). Effective CEO incentive compensation and sound corporate governance align the interest of management with the firm by forming correct and efficient decision on positive-feedback social activities. This paper examines whether media coverage, compensation and corporate governance act as positive moderators for the relationship between corporate social responsibility (CSR) and corporate financial performance (CFP), namely, CSR-CFP nexus. Based on data of TWSE-listed companies during 2005-2009, regression result generally shows that higher CEO compensation strengthen positive relationship between firm's CSR engagement and financial performance. Weaker corporate governance deteriorates positive CSR-CFP relationship. Media coverage has little influence on the relationship between CSR and CFP. Robustness checks such as fixed/random effect estimation, two-stage estimation and propensity score matching to control for selection bias yield similar outcome.
\end{abstract}

Keywords: CSR, CFP, media coverage, corporate governance

\section{Introduction}

Under the initiation of green revolution and environmental protection in recent decades, operation with sustainability becomes a main goal for a company and even for government regulation change. Specially, the milk scandal in China, the Wall Street greed (such as Enron and World.Com) and the Madoff scandal in the U.S have called company's management pay more attention on business morality and reputation. The business should focus not only on economic and financial benefit but also on social and environmental consequence.

According to the World Business Council for Sustainable Development (WBCSD), CSR is defined as "the continuing commitment by business to contribute to economic development while improving the quality of life of the workforce and their families as well as of the community and society at large". The definition of CSR from European Union (EU) is "a concept whereby enterprises integrate social and environmental concerns in their business operations and in their interaction with their stakeholders on a voluntary basis". International Organization of Employers (IOE) defined CSR as "initiatives by companies voluntarily integrating social and environmental concerns in their business operations and in their interaction with their stakeholders". Frooman (1997) defined CSR as "an action by a firm, which the firm chooses to take, that substantially affects an identifiable social stakeholder's welfare". McWilliams and Siegel (2001) described CSR as "actions that appear to further some social good, beyond the interest of the firm and that which is required by law".

As the global cry for repairing corporate reputation, business has realized the flood of management philosophy and struggled to balance financial performance with social and environmental responsibility. While the focus and angle of CSR among industry is not identical, some of them adopt eco-efficiency indicator to evaluate and control for environmental protection performance during operation, some of them incorporate social responsible criterion into corporate governance decision, and most of them publish CSR reports to demonstrate the efforts on CSR engagement. Anecdotal evidence such IBM employed the "Green Sigma" regulating company's quality management strategy to energy-saving/carbon emission reducing efforts and helped to monitor carbon emission, water resource and waste disposals and avoid potential waste of energy. The Abbott reserves $10 \%$ of its revenue for research and development and uses corporate website as the intermediary to report global citizen activities to 
meet the requirements of the Global Reporting Initiative's "Sustainability Reporting Guidelines". In Taiwan, Delta's founder and board chair, Bruce Cheng, believes in the spirits of CSR and emphasizes that what corporation take from the society should return to the society and it is difficult for corporation to exist without healthy social environment. Delta's mission is to "offer energy efficiently and innovative product that lead to a better quality of life" and pursuits of developing environmentally safe product combined with "love-the-earth" activity. Delta's display of quality, innovation, and agility in its corporate culture resulted in the company won "best supplier of the year" awards from large multinational corporations such as Microsoft and Cisco.

In recent decades, the academics have tried to discover and examine CSR issue, theoretically and empirically. While doing CSR has become a trend for global management philosophy, the inquiry about whether doing CSR is worth by CFP remains unsolved. Is firm's donation a purely public relationship expense or it has the ability of building firm's reputational capital for the future? Evenly, how long a firm retrieves inputted resource and then by what mechanism? If the answer and mechanism is unclear, doing CSR may not be a long-run optimal strategy. Conversely, if CSR action could earn money to recover its cost, firm and the society could reach win-win situation.

Theoretically, Freeman (1984) proposed stakeholder theory to suggest that investing resources to address stakeholder's interest is a justifiable managerial activity. Cornell and Shapiro (1987) emphasized that the relationship between a firm and its stakeholder's interest provides an overlooked connection between corporate strategy and corporate well-being. Dishonest conduct towards one stakeholder leads other stakeholders to doubt whether company will still respect their own interests. Thus, a company should take care of interests towards all its stakeholders and take into account interactions and influences that the impacts of one decision on one particular stakeholder and its perception by another. Preston and O'Bannon (1997) suggested that if firm could satisfy the requirements among stakeholders, their performance would be better.

On the other hand, Friedman (1970) proposed that "there is one and only one social responsibility of business to use its resources and engage in activities designed to increase its profits so long as it stays within the rules of the game, which is to say, engages in open and free competition without deception or fraud". The purpose of companies is to make profits and reward its shareholder, thus the firm's spending resources on philanthropy and unnecessarily on "doing good" project is economically unethical. Bragdon and Marlin (1985) and Vance (1975) argued that firm with high responsibility may incur additional cost that suffers economic disadvantage. Added cost may result from action such as making expensive and extensive charitable contribution, promoting community development plan, maintaining plant in economically depressed location and establishing environmental protection procedure. In addition, concern for socially responsibility may limit a firm's strategic choice, for example, forgo certain product line such as weapon and these cost put responsible firm at an economic disadvantage (Aupperle, Carroll and Hatfield, 1985; Friedman and Friedman, 1981; Ullmann, 1985). Walley and Whitehead (1994) argued that it is hard for company to come up with "win-win" project and environmental regulation may destroy stock market performance. Other extant studies are referred to Margolis and Walsh (2003), Barnett and Salomon (2006).

Empirically, extant research about the relationship between CSR and corporate financial performance (CFP) are fruitful but inconclusive. Moskowitz (1972) developed "reputation index" rating firm as outstanding, honorable mention and worst companies, for the proxy of CSR measurement. Moskowitz (1972) found that firms with higher CSR ratings tend to outperform the market, thus revealed positive correlation between CSR and CFP. McGuire, Sundgren and Schneeweis (1988) used the Fortune magazine's ratings of corporate reputation to examine the corporate responsibility/performance relationship. They found that firm's prior performance (stock market returns and accounting-based measure) largely relate to CSR than subsequent performance. They also found negative relationship between social responsibility and corporate risk. Waddock and Graves (1997) employed reputation ratings developed by Kinder, Lydenberg and Domini (KLD) as the proxy of CSR and found that past and current KLD ratings is positively related to firm's returns on assets. Tsoutsourz (2004) employed KLD ratings and confirmed the result with positive relationship between CSR and returns on assets, returns on equity and returns on sales. Similar studies are referred to Spicer (1978), Chen and Metcalf (1980), Mahapatra (1984), Russo and Fouts (1997), Thomas (2001), Ziegler, Rennings and Schröder (2002) and King and Lennox (2002).

Conversely, Vance (1975) applied the ratings by Moskowitz's reputational survey and found negative relationship between social performance and stock price changes. Newgren, Rasher, LaRoe and Szabo (1985) compared the performance of firms with environmental assessment and those firms without assessment. They found that firm employing environmental assessment is underperformed thus suggested a negative CSP-CFP relationship. Based on the Ethical Investment Research Service (EIRIS) which specializes in the measurement of 
corporate social performance, Brammer, Brooks and Pavelin (2006) found that the score on composite social performance indicator is significantly and negatively related to stock returns, and the poor returns is attributable to good social performance on the employment and to lesser extent on environmental aspects. Interestingly, considerable abnormal returns are available from holding a portfolio of the least socially desirable stocks. Anginer, Fisher and Statman (2008) employed the Fortune magazine's annual list of "America's Most Admired Companies" during 1983 and 2006 and found that stocks of admired companies had lower returns, on average, than stocks of despised ones. Review of empirical studies about the relationship between CSR and CFP is referred to Barnett and Salomon (2006), Orlitzky, Schmidt and Rynes (2003), Mishra and Suar (2010), Yang, Lin and Chang (2010) and Surroca, Tribo and Waddock (2010).

Barnett and Salomon (2006) found a curve-linear relationship between CSR and CFP. Margolis and Walsh (2003) stressed the importance of developing model that incorporate omitted variables, test mediating mechanism and contextual condition, and establish causal link between social performance and financial performance. Margolis and Walsh (2003) indicated that existing research lack of engaging in identifying sampling problem, concerning about the reliability and validity of CSR and CFP measurement, omission of control variable, tested mediating mechanism and moderating condition (Aldag \& Bartol, 1978; Arlow \& Gannon, 1982; Cochran \& Wood, 1984; Aupperle, Carroll, \& Hatfield, 1985; Wokutch \& McKinney, 1991; Wood \& Jones, 1995; Pava \& Krausz, 1996; Griffin \& Mahon, 1997; Preston \& O’Bannon, 1997; Richardson, Welker, \& Hutchinson, 1999; Roman, Hayibor, \& Agle, 1999; Margolis \& Walsh, 2001; Orlitzky, Schmidt, \& Rynes, 2003). Margolis and Walsh (2003) advised that future research could work toward above direction.

McWilliams and Siegel (2000) argued that most of empirical model for CSR-CFP relationship are mis-specified because they lack of controlling for investment in R\&D, which has shown to be an important determinant of firm performance and thus the CSR effect on performance will be upward bias. Russo and Fouts (1997) found that firm's environmental performance and economic performance is positively correlated and industry growth is a moderator between above relationship. Greater environmental performance leads to higher economic performance as the growth of industry is higher. Based on the resources-based view, Surroca, Tribo and Waddock (2010) argued that firm's intangible resource acts as mediator for the relationship between CSR and FP. They found that there is no direct relationship between CSR and CFP-merely an indirect relationship that relies on the mediating effect of a firm's intangible resource. Chang and Shen (2011) showed that CSR-firm tends to have superior credit ratings. Better credit ratings is related to greater profitability, thus credit ratings (proxy for the cost of debt) plays a mediating role of the relationship between CSR and CFP. Based on the literature development mentioned above, this paper tries to propose and examine three moderators between CSR and CFP, namely, news exposure, CEO incentive compensation and corporate governance (proxied by director's and supervisor's shareholdings pledge ratio). Reasons are below.

First, the prerequisite for getting better firm performance by engaging in philanthropic activities is the public perception and realization of the contribution. News exposure may help their benevolent action under the sunlight (known by the public). Frequent exposure for a firm helps them obtain higher and better reputation perceived by potential consumers or other stakeholders, and the better performance will get when doing CSR. According to Chih, Chih, and Huang (2010), information about a firm' s CSR activities may not be known to the public and insufficient for stakeholders to give a positive and significant feedback toward firm. Schuler and Cording (2006) argued that if the information about of a firm's social activity is provided by external source, such as the media, there is higher likelihood of consumer awareness about the information. The marginal benefit on corporate performance by adopting CSR may be larger as firm's news exposure of is more frequent.

Second, due to the separation for ownership and control right, although some firms establish charitable foundation, their purposes might be tax shields for high-level managers and thus have little help for proletariat populace and financial performance for firm. Particularly, a socially responsible firm is willing to sacrifice short-term profits to engage in social and environmental activities in return for longer-term sustainability. Thus, a company should use executive incentive compensation (such as stock option, stock bonus and cash bonus) to encourage management to act toward the interests not only of shareholders but also stakeholders (Marens, 2002). Higher incentive compensation for management will encourage them doing CSR activities that really help for long-term profitability for firms. Thus, the marginal increase in performance due to CSR actions might be larger as firm's level of CEO incentive compensation is higher.

Jensen and Meckling (1976) proposed convergence-of-interest hypothesis that as the management ownership is high, operational loss is going to hurt their own interests, and thus they have a greater incentive to improve the company's operating performance. On the other hand, Jensen and Ruback (1983) proposed conflict of interest hypothesis that when the management ownership is high, the management themselves enjoy enough voting 
power and feel their job is stable and comfortable, sometimes they may also perform some anti-takeover behavior, thus lead to lower incentive and deterioration of firm's operating performance. The proportion of directors and supervisors' shareholdings under pledged may also has two effects that are similar with their shareholdings. If pledge ratio is low, they are more likely to oversee and make efforts on improving company's performance. However, if the pledge ratio is high, they might be use improper practices to maintain the company's share price or take risky investment, thus the company might result in poor performance. Here, we propose that both views have own possibilities, pledge ratio can either positively moderates the effects of CSR on CFP, because of convergence-of-interest hypothesis, or negatively moderates the effects of CSR on CFP, because of conflict of interest hypothesis.

The main purpose of this paper is to examine whether news exposure, CEO incentive compensation and corporate governance (proxied by director's and supervisor's shareholdings pledge ratio) moderate the relationship between CSR and CFP. Based on the data of TWSE (Taiwan Stock Exchange)-listed companies during 2005 and 2009, regression result generally shows that CEO incentive compensation is a significant and positive moderator between CSR and CFP, worse corporate governance weakens the positive relation between CSR and CFP, and news exposure is not a significant moderator. The remainder of this paper is as followed. The next section validates the reasons for above three moderators between CSR and CFP. Section 3 describes variables, data and econometric model. Section 4 reports empirical result, explanation and managerial implication. The last section concludes.

\section{Moderating Effect of the Relationship between CSR and CFP}

While the public and the contemporary management philosophy generally accept the importance of CSR, the prerequisite for getting better firm performance by engaging in philanthropic activities is the public perception and realization of the contribution by doing CSR. News exposure of a company may help their benevolent actions under the sunlight (known by the public). According to Chih, Chih and Huang (2010) and Schuler and Cording (2006), while extant studies postulated positive or negative correlations between CSR and CFP, four conditions still need to be considered. First, information about CSR activities of a firm is available; second, stakeholders are aware of the information; third, stakeholders' moral values emphasize other-regarding (relative to self-regarding) characteristics, and finally, stakeholders are motivated to engage in supportive (or deleterious) behavior toward the firm. Any of these four conditions not hold, the relationship between CSR and CFP is expected to collapse. Therefore, stakeholders need to have available and relevant information about firm's CSR activity to motivate them to engage in supportive (or deleterious) behavior toward the firm which in turns bring about positive (or negative) consequences on firm financial performance.

Fombrun and Shanley (1990) observed that the media themselves act as a vehicle for advertising and mirror of reality reflecting firms' action. McWilliams and Siegel (2001) argued that media coverage heightens customer awareness of CSR behaviors of firm, thus media coverage plays as central role in process of recording and transmitting CSR information from firm to the public. An informal essay written by Jasper Blake, stressed the importance of social media in creating awareness of social and environmental issues and highlights the close relationship between the rise of information availability and CSR engagement:"Consumers are increasingly making purchase decisions based on how good a brand is relative to its impact on society, because they see it as an opportunity to have a positive impact on the world, even if only in small ways. The transparency of digital technology makes it easy for them to see which brands are doing the best job at being socially responsible. If consumers don't get the intrinsic link between brand benefit and social purpose, they won't buy it, literally or figuratively".

Based on Barney (1991) and Hall (1992)'s proposition that a positive reputation is a resource contributing to competitive advantage, Deephouse (2000) provided theoretical and empirical support for media reputation is a strategic resource (intangible resource) which leads to competitive advantage and superior financial performance of commercial banks. Deephouse (2003) found evidence supporting the role of information as a mediator in the CSR-CFP relationship. Different from Deephouse (2003), this paper proposes that the media plays a moderating role between CSR and CFP, because when a firm's frequency of news exposure is higher, more information about firm's CSR activity is obtained by stakeholder. Based on Schuler and Cording (2006), it has higher possibility that doing CSR will bring more positive feedback on CFP. News exposure is a positive moderator of the relationship between CSR and CFP.

While doing CSR is a consensus in practice, the range for CSR action is broadly but unclearly defined. One may concern that whether the management establishes a foundation and donates firm's resources there (may be for the purpose of tax avoidance) to hold meal meeting or art performance for the high officials and the nobles. The 
general public and interesting stakeholder are unable to be intimate with it and benefit from such CSR activity. Thus, how to motivate the management to form CSR behavior that really takes care of stakeholders, enhances sustainability and thus improves performance is an important point.

Based on Jensen and Meckling (1976), Holmstrom (1979) and Amihud and Lev (1981), an important mechanism of corporate governance is an effective executive compensation structure, which is widely used to reward executives for hard-working toward particular corporate goals and favorable outcomes. While Mahoney and Thorne (2005) argued that fixed and shorter-term incentive compensation plan is assumed to motivate executive' $\mathrm{s}$ consideration about immediate performance and longer-term compensation which is based on market valuation tends to motivate executives' consideration about sustainability. Mahoney and Thorne (2006) found evidence that different component of executives' compensation: salary, bonus and stock option has different impact on firm's CSR behavior. Because CSR activity which really helps improve corporate performance need managers to give up personal interest to pursuit for company's interest, longer-term incentive compensation is relative suitable. Higher level of CEO incentive compensation, the management has larger motivation to do the CSR activity which really benefit stakeholders and thus have positive feedback on firm performance. The level of CEO incentive compensation is a positive moderator for the relationship between CSR and CFP.

Jensen and Meckling (1976) proposed convergence-of-interest hypothesis to suggest that as the management ownership is high, operational loss is going to hurt their personal interest, and thus they have greater incentive to improve the company's operating performance. Leland and Pyle (1977), Kesner (1987) and Oswald and Jahera (1991) proposed that higher managerial shareholdings connects personal interest with interest of corporation. Oswald and Jahera (1991), Hudson, Jahera and Lloyd (1992), Vance (1995) and Yermack (1996) supported the proposition. On the other hand, Jensen and Ruback (1983) proposed conflict of interest hypothesis to describe that as management ownership is high, the management themselves enjoy enough voting right and feel their job is stable and comfortable, sometimes they may also perform some anti-takeover behavior, thus lead to lower incentive and deterioration of firm's operating performance. The evidence of Fan and Wong (2002) supported the proposition of Jensen and Ruback (1983).

When the managerial shareholdings is high, and when they make a decision about strategic choice of CSR activity, they will prefer a CSR action toward the stakeholders interests which has higher possibility to positively feedback on firm's performance as well as their resulting payoff. Therefore, the level of management or directors shareholdings is a positive moderator of the relationship between CSR and CFP. The proportion of directors and supervisors' shareholdings under pledged has two effects that are similar with managerial shareholdings. If pledge ratio is low, they are more likely to oversee and make efforts on improving company's performance. However, if the pledge ratio is high, they might be use improper practices to maintain the company's share price or take risky investment, thus the company might result in poor performance. While both views have possibilities, pledge ratio can either positively moderates the effects of CSR on CFP by convergence-of-interest hypothesis or negatively moderates the effects of CSR on CFP by conflict of interest hypothesis. The marginal increase in performance from doing CSR might be larger when firm's ratio of directors and supervisors' shareholdings under pledged is higher (or lower).

\section{Variable, Econometric Model and Data}

\subsection{Variable}

\subsubsection{Corporate Financial Performance}

According to Griffin and Mahon (1997), in the research of relationship between CSR and CFP, measurement for financial performance indicator can be divided into two types, one is accounting-based indicator, such as return on assets, returns on equity, the other is market-based indicator, such as stock returns and Tobin's Q. Both of them have advantages and disadvantages. While accounting-based indicator catches firm's historical performance, market-based indicator is forward-looking. However, market-based indicator is subjective and maybe biased by irrational investors and market noise (McGuire et al., 1988). Moore (2001) pointed out that in assessing CSR and CFP relationship, accounting indicator is better than market-based one. This paper employs accounting-based indicators, namely, returns on assets $(R O A)$, returns on equity $(R O E)$, returns on sales $(R O S)$, operating profit margin (OPERA) and earnings per share (EPS) to proxy for CFP. Based on market-based indicator, Chang $(2009,2011)$ engaged in the analysis for relationship between CSR and stock returns and found that firm with superior performance on CSR tends to perform well on accounting-based indicators but market-based indicators, namely, firm with superior performance on CSR firms may not be good investment for investors. 


\subsubsection{CSR Measurement}

For the development of CSR measurement, Bragdon and Marlin (1972), Folger and Nutt (1975) and Spicer (1978) developed CSR measure based on firm's pollution control effort, environmental protection effort and social reputation. Heinze (1976) employed a more subjective, non-quantitative indicator such as survey for company's impression on CSR performance from business school student. The Fortune magazine investigated corporation social prestige ranking and were wildly applied by academics (McGuire et al., 1988; Herremans, Akathaporn, \& McInnes, 1993; Preston \& O'Bannon, 1997). In 2001, the London Stock Exchange and the Financial Times, established FTSE, and created an index about CSR (FTSE 4GOOD index series). Companies included in that index series are based on five criteria: (1) towards environmental sustainability of efforts; (2) the development of positive relationship with stakeholder; (3) the concern for human right issue and support; (4) to ensure a good supply chain labor standard; (5) against bribery. FTSE 4GOOD Index series also excluded companies which their operation involved with tobacco, nuclear weapons and research/development of uranium. Index series include U.S., U.K and Europe. The index in each region is firstly compiled by the initial area (starting universe), and then select companies as a high degree of social responsibility to be constituent of the index.

In 2005, one of the leading business magazine in Taiwan, the Global Views Monthly (GVM), developed a framework on evaluating social responsibility of TWSW-listed companies from three dimensions, performance on community participation, environmental protection and financial transparency. The GVM refers to Germany social responsibility research institution, OEKOM's score weighting criteria, including corporate social performance, environmental performance and financial information, as three part of concern and construct questionnaire about engagement and effectuation of the above three aspects for listed companies on the Taiwan Stock Exchange (TWSE). They computed score on each three dimension of CSR activity based on respondents' reply. Then, they ranked company according to their total scores of above three aspects.

The GVM also check: (1) negative reports at news; (2) external audit agencies (such as the EPA, Council of Labor Affairs, the Consumer's Foundation and public interest groups, etc.); (3) in past two years whether there have been major labor disputes, environmental protection and public nuisance action cases, consumer disputes and the management fraud or leave; (4) whether firms were operating losses for three consecutive years. Then they ranked companies according to their total scores of above three aspects. The announcement of ranking result is on May every year since 2005. Finally, they conferred CSR-Award to companies what scores are relatively higher. The measurement for CSR is indicated by a dummy variable $\left(D_{C S R}\right)$, that's when a company wins CSR-Award, it is CSR-firm and $D_{C S R}$ is equal to 1, otherwise, it is Non-CSR-firm and $D_{C S R}$ is equal to 0. It is important to note that, in this paper, once a firm wins CSR Award, we define it as a CSR-firm. Name-list of winners of CSR-Award is reported in Table 1.

To measure firm's new exposure (NEWS), based on the Management System for News and Knowledge of Legislative Yuan (http://nplnews.ly.gov.tw/), this paper searches for frequency of news exposure on all newspapers (China Times, United Daily News and Liberty Times) in Taiwan for each year. We are not going to divide these news into good news and bad news, because we are not going to examine the direct effects of news exposure on firm performance. Instead, we propose that news exposure as moderator for marginal impacts of CSR on CFP. Other research uses similar concept such as Chih, Chih and Huang (2010) for Taiwan's two largest newspapers. Robinson and Levy (1996) and Gaines-Ross (2000) suggested that newspapers provide the most powerful media coverage. In this paper, firm's media coverage is limited to its exposure on domestic major newspapers.

Two things worth noting, first, as running regression which relating CSR engagement to CFP, other control variables for financial performance are further considered. This paper employs four controls, total assets $(A S S E T)$, debt ratio (DEBT), research and development expense ratio $(R D)$ and the revenue growth rate $(S A L E S G)$. Second, in regression equation, while explanatory variable and explained variable are contemporaneous, possible reverse causation problem exists. Therefore, this paper runs an additional regression such that explained variable is subsequent period relative to explanatory variable. 
Table 1. TWSE-listed CSR-firms

\begin{tabular}{|c|c|c|c|c|}
\hline Year & \multicolumn{4}{|l|}{ Company Name } \\
\hline \multicolumn{5}{|l|}{2005} \\
\hline & \multirow{4}{*}{\multicolumn{2}{|c|}{$\begin{array}{l}\text { Lite-On Technology Co. } \\
\text { Delta Electronics, Inc. } \\
\text { Taiwan Mobile Co. } \\
\text { China Motor Co. }\end{array}$}} & \multicolumn{2}{|c|}{ Taiwan Semiconductor Manufacturing Company } \\
\hline & & & \multicolumn{2}{|l|}{ Accton Technology Co. } \\
\hline & & & \multirow{2}{*}{\multicolumn{2}{|c|}{ President Chain Store Co. }} \\
\hline & & & & \\
\hline \multicolumn{5}{|l|}{2006} \\
\hline & \multirow{2}{*}{\multicolumn{2}{|c|}{$\begin{array}{l}\text { Taiwan Semiconductor Manufacturing Company } \\
\text { Delta Electronics, Inc. }\end{array}$}} & AU Optronics Co. & Lite-On Technology Co. \\
\hline & & & Advantech Co. & Wah Lee Industrial Co. \\
\hline & \multicolumn{2}{|c|}{ President Chain Store Co. } & Sinyi Real ty Inc. & China Airlines \\
\hline & \multicolumn{2}{|c|}{ China Motor Co. } & \multicolumn{2}{|l|}{ Yulon-Nissan Motor Co. } \\
\hline & \multicolumn{2}{|c|}{ Uni-President Enterprises Co. } & & \\
\hline \multicolumn{5}{|l|}{2007} \\
\hline & \multicolumn{2}{|c|}{ Delta Electronics, Inc. } & Chimei Innolux Corp. & Lite-On Technology Co. \\
\hline & \multicolumn{2}{|c|}{ Advantech Co. } & MediaTek Inc. & AVerMedia Technologies Inc \\
\hline & \multicolumn{2}{|l|}{ Chunghwa Telecom } & Sinyi Realty Inc & Taiwan Mobile Co. \\
\hline & \multicolumn{2}{|l|}{ China Motor Co. } & \multicolumn{2}{|l|}{ Yulon-Nissan Motor Co. } \\
\hline & \multicolumn{4}{|c|}{ Uni-President Enterprises Co. } \\
\hline \multicolumn{5}{|l|}{2008} \\
\hline & \multicolumn{2}{|c|}{ Chimei Innolux Corporation } & UMC & Lite-On Technology Co. \\
\hline & \multicolumn{2}{|l|}{ Camel Precision Co. } & ZyXEL Communications Co. & MediaTek Inc. \\
\hline & \multicolumn{2}{|l|}{ Hotai Motor } & Sinyi Realty Inc & President Chain Store Co. \\
\hline & \multicolumn{2}{|l|}{ Yulon Motors } & \multicolumn{2}{|l|}{ Pou Chen Group. } \\
\hline & \multicolumn{4}{|c|}{ TECO Electric and Machinery Co. } \\
\hline \multicolumn{5}{|l|}{2009} \\
\hline & Sinyi Realty & Advantech Co. & \multicolumn{2}{|l|}{ President Chain Store Co. } \\
\hline & Chunghwa Telecom & Yulon Motors & \multicolumn{2}{|l|}{ AU Optronics Co. } \\
\hline & \multicolumn{2}{|c|}{ Taiwan Semiconductor Manufacturing Company } & \multicolumn{2}{|l|}{ Uni-President Enterprises Co } \\
\hline & \multicolumn{2}{|c|}{ ZyXEL Communications Corp } & Macronix International Co., $\mathrm{Lt}$ & \\
\hline
\end{tabular}

Notes. This table reports name-list for winners of CSR-Award from the Global Views Monthly. Detailed information about CSR-Award is referred to http://www.gvm.com.tw/CSR2010/index.html. Financial institution is excluded.

For measurement for CEO incentive compensation, while more bonus (cash bonus versus stock bonus) relative to the net income provides greater incentive for managers to engage in the firm's interest instead of personal interest, and thus pay more effort on profit maximizing behavior. For same reason, more employ stock option for manager encourages them pay more attention on corporate interest, thus higher employee stock option relative to firm's earning implies higher incentive for manager. While bonus provides relative shorter-term incentives and stock option provides longer-term incentive, they are distinguished. Because this paper lacks of detail and complete data on bonus as well as stock option for every member on the management/board for most TWSE-listed companies, average manager's (including directors and supervisors) total salary and payment (INCENTIVE) is a proxy for firm's incentive compensation. The pledge ratio is defined as director's and supervisor's shareholdings pledge ratio (PLEDGE). The definition and calculation of all variables is reported in Table 2.

\subsection{Econometric Model}

Our econometric method is based on multivariate regression analysis. Regression equation is:

$$
\begin{gathered}
\text { PERFORMANCE }_{i t}=\beta_{0}+\beta_{1} D_{C S R, i t}+\beta_{2} A_{S S E T_{i t}}+\beta_{3} D E B T_{i t}+\beta_{4} R D_{i t}+\beta_{5} S A L E S G_{i t}+\varepsilon_{i t} \\
\beta_{1}=\alpha_{0}+\alpha_{1} N E W S+\alpha_{2} I N C E N T I V E+\alpha_{3} P L E D G E
\end{gathered}
$$

where PERFORMANCE is proxied by five performance variables, namely, ROA, ROE, ROS, OPERA and EPS. $D_{C S R}$ is a proxy for firm's social responsibility performance, when a firm wins CSR-Award from the Global Views Monthly, the $D_{C S R}$ is equal to one, and 0 otherwise, such that $D_{C S R}$ is a dummy variable. ASSET is total assets of a firm. $D E B T$ is debt ratio. $R D$ is a ratio of R\&D expense to net sales. SALESG is the rate of growth of net sales. INCENTIVE measures firm's incentive compensation and is defined as average managers, directors and supervisors' total salary and payment. PLEDGE is the director's and supervisor's shareholdings pledge ratio 
which is calculated as director's and supervisor's shareholdings under pledged divided by their total shareholdings. NEWS is the number (frequency) of news exposure on all newspapers in Taiwan.

Table 2. Mnemonics and definition of variables

\begin{tabular}{ll}
\hline Variable & Definition \\
\hline $\boldsymbol{D}_{\text {CSR }}$ & A dummy variable which equal to one if firm is winner of "CSR Award" (interchanged with CSR-firm). \\
$\boldsymbol{A S S E T}$ & Otherwise, it is equal to zero (interchanged with NonCSR-firm). \\
$\boldsymbol{D E B T}$ & Current Assets + long-term investment + total fixed assets + total other assets \\
$\boldsymbol{R D}$ & Total liability/total assets \\
$\boldsymbol{S A L E S G}$ & (Research and development expenses) /net sales \\
$\boldsymbol{N E W S}$ & (Net sales a time t -net sales at time t-1) / net sales at time t-1| \\
$\boldsymbol{I N C E N T I V E}$ & Number of exposure in all national-wide newspapers in Taiwan \\
$\boldsymbol{P L E D G E}$ & Average directors and supervisors' total salary and payment \\
$\boldsymbol{R O A}$ & Directors and supervisors shareholdings pledge ratio \\
$\boldsymbol{R O E}$ & Net income / average total asset \\
$\boldsymbol{R O S}$ & Net income / average total equity \\
$\boldsymbol{O P E R A}$ & Gross profit (margin) on sale / net sales \\
$\boldsymbol{E P S}$ & Operating profits /net sales \\
\hline
\end{tabular}

Notes. The definition of variables comes from the Taiwan Economic Journal, Management System for News and Knowledge of Legislative Yuan and the Global Views Monthly.

If the estimated coefficient on $D_{C S R}$ is significantly positive, it means that a firm with CSR tends to have higher financial performance. If estimated coefficients on three product term, $D_{C S R}$ and NEWS, $D_{C S R}$ and INCENTIVE, $D_{C S R}$ and PLEDGE are significantly positive, it means that as news exposure, incentive compensation and director's and supervisor's shareholdings pledge ratio are higher, adopting CSR (thus being CSR-firm) tends to have superior performance (relative to the situation when news exposure, incentive compensation and director's shareholdings and supervisor's shareholdings pledge ratio are lower). The focus of empirical part of this paper is on the sign and significance of these estimated coefficients.

According to Shen and Chang (2009), because our CSR measure is a dummy variable, means that some of firms are CSR firms and others are not. One may concern that the classification of them is not a random process and may be endogenously determined, for example, firms with better performance in the past tend to adopt CSR because they have excess profit or enough resource to engage in CSR and thus are selected by the $G V M$ for CSR-Award winners. If this possibility exists, estimated coefficient on CSR dummy does not purely capture the effect of CSR on CFP, it also capture the effects of some specific variables which smuggle the factors affecting samples to be CSR firm or not to be CSR firms. This possibility of CSR dummy to be correlated with the regression residuals is going to create sample selection bias problem (Heckman, 1979).

Heckman (1979) suggests using two-stage estimation to eliminate sample selection bias. The first step is to estimate a probability model which determines samples are included in CSR-firm or not. The resulting Inverse Mill's Ratio serves as additional explanatory variable in performance equation, namely, the regression equation in the second step. Alternatively, Rubin $(1973,1977)$ developed matching theory, and then Rosenbaum and Rubin (1983, 1985a,b) proposed Propensity Score Matching (PSM), both are alternative methods to eliminate sample selection bias in the extant studies. The basic concept of Rubin (1973a,b) is that non-participants of experiment (firms without doing CSR) that have similar characteristics with participants (CSR firms) are called the controlled samples. The changes owing to the experiment between treatment sample and control sample is referred to as experimental or treatment effect (purely doing CSR effects). The PSM firstly estimate the probability of including in the experiment by all samples using characteristic variables as the explanatory variables. Then for each firm in the treatment sample, firms in the control samples are selected as matched samples according to the closeness of the above estimated probability. See Shen and Chang (2009) for detail.

This paper employs Heckman (1979)'s two-stage and Rosenbaum and Rubin (1983, 1985a,b)'s PSM to correct for possible sample selection bias as robustness checks. For simplicity, characteristic variables are ASSET (natural $\log$ of current-period total assets), LDEBT (last-period debt ratio) and LPROFITL (last-period after-tax profits levels). 


\subsection{Data}

Our samples are TWSE-listed companies (financial firms are excluded) covering the period of 2005 2009. The CSR measurement is based on annual announcement for name-list of CSR-Award by the Global Views Monthly. The financial data, incentive compensation of sample firms is collected from the Taiwan Economic Journal (TEJ) database. Frequency of firm's news exposure is calculated from the Management System for News and Knowledge of Legislative Yuan. Yearly data is employed.

\section{Empirical Results}

This paper has 86 CSR-firm and 3,454 NonCSR-firm-year samples, respectively. Data of variables which the value exceeds three standard deviation around its mean is deleted to get rid of biased by outlier. Table 3 reports basic statistics of characteristics and performance variables for all samples, samples of CSR-firm and NonCSR-firm.

We observe that CSR-firm tends to have larger total assets than NonCSR-firms (17.5006 versus 15.5708). The average DEBT and SALESG are lower for CSR-firms (33.3733 versus 36.8301 and -0.11895 versus 12.8727 , respectively), represents that CSR-firm tends to have lower debt ratio and lower growth rate of net sales. The $R D$, research and development expense to sales, is relative higher for CSR-firms (3.69756 versus 2.61905). For CSR-firm, NEWS, INCENTIVE and PLEDGE are relative higher than NonCSR-firm, on average (146.419 versus $54.2775,2504.34$ versus 927.878 and 10.1615 versus 8.74408 , respectively), means that CSR-firm tends to have higher frequency on news exposure, higher average incentive compensation and higher director's and supervisor's shareholdings pledge ratio. By observing statistics of five performance variables, we find that all of them are higher for CSR-firm, means that CSR-firm tends to have superior performance than NonCSR-firm.

Table 4 reports the Pearson correlation coefficient matrix between variables. From the first column, we observe that correlation coefficient between $D_{C S R}$ and ASSET is -0.232 and reaches statistical significance, means that firm with larger assets tends to be CSR-firms. Correlation coefficient between $D_{C S R}$ and DEBT is -0.0315 , between $D_{C S R}$ and $R D$ is 0.0387 , and both are significant, means that CSR-firms tends to have lower debt ratio and higher research and development expense to net sales. The correlation coefficients between DCSR and NEWS, $D_{C S R}$ and INCENTIVE, $D_{C S R}$ and PLEDGE are 0.1655, 0.1836 and 0.0141, and the former two reach statistical significance, which represents that CSR-firm tends to have higher frequency of news exposure and higher average managerial, director's and supervisor's total salary and payment. As we observe the correlation coefficients between $D_{C S R}$ and five performance variables, we find that they are all significantly positive, means that CSR-firm tends to perform better than NonCSR-firms on five performance measures.

Table 3. Descriptive statistics

\begin{tabular}{|c|c|c|c|c|c|c|c|c|c|c|c|c|}
\hline & \multicolumn{4}{|c|}{ All Samples } & \multicolumn{4}{|c|}{ CSR-firms } & \multicolumn{4}{|c|}{ NonCSR-firms } \\
\hline & Mean & St. dev. & Min. & Max. & Mean & St. dev. & Min. & Max. & Mean & St. dev. & Min. & Max. \\
\hline$D_{C S R}$ & 0.0243 & 0.1540 & 0.0000 & 1.0000 & 1.0000 & 0.0000 & 1.0000 & 1.0000 & 0.0000 & 0.0000 & 0.0000 & 0.0000 \\
\hline ASSET & 15.612 & 1.1981 & 11.873 & 19.488 & 17.501 & 1.1015 & 15.336 & 19.345 & 15.571 & 1.1668 & 11.873 & 19.488 \\
\hline$D E B T$ & 36.745 & 16.967 & 0.0700 & 89.480 & 33.373 & 18.306 & 11.210 & 85.930 & 36.830 & 16.926 & 0.0700 & 89.480 \\
\hline$R D$ & 2.6456 & 4.3206 & 0.0000 & 45.770 & 3.6976 & 4.5240 & 0.0000 & 24.420 & 2.6191 & 4.3128 & 0.0000 & 45.770 \\
\hline SALESG & 12.554 & 113.71 & -100.00 & 3477.5 & -0.1190 & 19.605 & -46.400 & 63.710 & 12.873 & 115.07 & -100.00 & 3477.5 \\
\hline NEWS & 56.252 & 80.606 & 0.0000 & 570.00 & 146.42 & 148.79 & 3.0000 & 526.00 & 54.278 & 77.327 & 0.0000 & 570.00 \\
\hline INCENTIVE & 960.51 & 1222.7 & 0.0000 & 7665.0 & 2504.3 & 1891.4 & 0.0000 & 6982.0 & 927.88 & 1183.4 & 0.0000 & 7665.0 \\
\hline PLEDGE & 8.7775 & 15.236 & 0.0000 & 69.670 & 10.162 & 16.232 & 0.0000 & 60.890 & 8.7441 & 15.212 & 0.0000 & 69.670 \\
\hline ROA & 7.8155 & 8.2766 & -20.970 & 36.480 & 12.394 & 8.3176 & -2.6800 & 33.530 & 7.6997 & 8.2439 & -20.970 & 36.480 \\
\hline$R O E$ & 8.4402 & 15.927 & -73.170 & 80.530 & 13.887 & 11.525 & -13.050 & 43.780 & 8.3035 & 15.999 & -73.170 & 80.530 \\
\hline ROS & 18.721 & 19.201 & -293.26 & 193.56 & 23.919 & 16.170 & -0.6100 & 59.650 & 18.590 & 19.255 & -293.26 & 193.56 \\
\hline OPERA & 4.2586 & 26.525 & -504.37 & 95.750 & 10.245 & 12.712 & -8.3100 & 42.030 & 4.1077 & 26.765 & -504.37 & 95.750 \\
\hline$E P S$ & 1.7501 & 2.7655 & -8.6700 & 12.870 & 2.7987 & 2.5642 & -7.1100 & 7.2200 & 1.7245 & 2.7657 & -8.6700 & 12.870 \\
\hline
\end{tabular}

Notes. See Table 2 for the definition of variables. Yearly data is ranged from 2005 to 2009. Data about variables which their value exceed three standard deviation around mean are deleted.

Table 5 reports pooled OLS estimation results of regression analysis of relating firm's five performance measures to CSR, control factors, and three cross-product terms. First, no matter which performance measure is used for explained variables, the estimated coefficient of CSR dummy is all positive, means that firm with CSR tends to perform well on these five measures. However, only when measures are ROA, ROE and EPS, the results 
are reaching statistical significance. Second, the estimated coefficient of cross product term of $D_{C S R}$ and NEWS

Table 4. Correlation matrix

\begin{tabular}{|c|c|c|c|c|c|c|c|c|c|c|c|c|c|}
\hline & (1) & (2) & (3) & (4) & (5) & (6) & (7) & (8) & (9) & (10) & (11) & (12) & (13) \\
\hline 1) $D_{C S R}$ & 1.000 & & & & & & & & & & & & \\
\hline 2) $A S S E T$ & $0.232^{*}$ & 1.000 & & & & & & & & & & & \\
\hline 3) $\mathrm{DEBT}$ & -0.032 & $0.153^{*}$ & 1.000 & & & & & & & & & & \\
\hline 4) $R D$ & $0.039^{*}$ & $-0.177 *$ & $-0.262^{*}$ & 1.000 & & & & & & & & & \\
\hline 5) $S A L E S G$ & -0.018 & $-0.067 *$ & $0.042 *$ & 0.013 & 1.000 & & & & & & & & \\
\hline 6) $N E W S$ & $0.166^{*}$ & $0.427 *$ & $0.0367 *$ & $-0.055^{*}$ & 0.009 & 1.000 & & & & & & & \\
\hline 7) INCENTIVE & $0.184^{*}$ & $0.481 *$ & $-0.051^{*}$ & $-0.042 *$ & 0.008 & $0.255^{*}$ & 1.000 & & & & & & \\
\hline 8) PLEDGE & 0.014 & $0.111^{*}$ & $0.112 *$ & -0.083 & $-0.050^{*}$ & 0.021 & 0.031 & 1.000 & & & & & \\
\hline 9) $\mathrm{ROA}$ & $0.088^{*}$ & $0.099 *$ & $-0.272^{*}$ & $0.071^{*}$ & $0.091 *$ & $0.093^{*}$ & $0.356^{*}$ & $-0.074 *$ & 1.000 & & & & \\
\hline 10) $R O E$ & $0.054^{*}$ & $0.099 *$ & $-0.162^{*}$ & -0.032 & $0.086^{*}$ & $0.077^{*}$ & $0.334^{*}$ & $-0.054 *$ & $0.845 *$ & 1.000 & & & \\
\hline 11) $\mathrm{ROS}$ & $0.043^{*}$ & $-0.087 *$ & $-0.288^{*}$ & $0.287 *$ & $0.063^{*}$ & -0.023 & $0.102 *$ & $-0.058^{*}$ & $0.437 *$ & $0.380 *$ & 1.000 & & \\
\hline 12) $O P E R A$ & $0.039^{*}$ & $0.104 *$ & $-0.137 *$ & -0.016 & $0.065^{*}$ & $0.044 *$ & $0.159 *$ & -0.015 & $0.417 *$ & $0.418^{*}$ & $0.483 *$ & 1.000 & \\
\hline 13) $E P S$ & $0.059^{*}$ & $0.144 *$ & $-0.171^{*}$ & -0.003 & $0.082 *$ & $0.092 *$ & $0.398^{*}$ & $-0.094 *$ & $0.822^{*}$ & $0.871^{*}$ & $0.339 *$ & $0.357 *$ & 1.000 \\
\hline
\end{tabular}

Notes. This table reports correlation coefficients among variables (numbers in parentheses are p-values for correlation coefficients). See Table 2 for the definition of variables. Yearly data are used and ranged from 2005 to 2009. There are 3,540 firm-year samples.

are all insignificant, means that no matter which performance is used, when a firm is CSR-firm, higher the frequency of news exposure is not going to increase or decrease firm performance. News exposure is not a moderator between CSR and firm performance. Third, the estimated coefficient on cross product term of $D_{C S R}$ and INCENTIVE are significantly positive when performance measures are ROE and EPS, means that higher average directors and supervisors' total salary and payment (thus higher incentive compensation) is going to enhance a firm's returns on equity and earnings per share. CEO incentive compensation is a positive moderator between CSR and CFP. Fourth, estimated coefficient on cross product term of $D_{C S R}$ and PLEDGE are all significantly negative no matter which performance measure is used, represents that higher directors and supervisors shareholdings pledge ratio is going to deteriorate a firm's performance, and thus conflict of interest hypothesis of Jensen and Ruback (1983) holds here. Directors and supervisors shareholdings pledge ratio is a negative moderator between CSR and CFP. Finally, for controls, regardless of which performance measure is used, estimated coefficient of ASSET is positive, for DEBT is negative and for SALESG is positive and all of them are significant, means that firm with larger assets, lower debt ratio and higher growth rate of net sales tends to perform well on these performance measures.

Table 5. Regression results of pooled estimation

\begin{tabular}{|c|c|c|c|c|c|}
\hline \multirow{2}{*}{$\begin{array}{l}\text { Explanatory } \\
\text { Variables } \\
\end{array}$} & \multicolumn{5}{|c|}{ Explained Variables } \\
\hline & $R O A$ & ROE & ROS & OPERA & $E P S$ \\
\hline$D_{C S R}$ & $\begin{array}{c}2.6964^{* *} \\
(2.28)\end{array}$ & $\begin{array}{c}4.0736^{* *} \\
(2.13)\end{array}$ & $\begin{array}{l}0.1587 \\
(0.06)\end{array}$ & $\begin{array}{c}2.0823 \\
(1.16)\end{array}$ & $\begin{array}{c}1.0774^{* * *} \\
(2.58)\end{array}$ \\
\hline ASSET & $\begin{array}{c}0.8412^{* * * *} \\
(31.3)\end{array}$ & $\begin{array}{c}1.0585^{* * * *} \\
(18.8)\end{array}$ & $\begin{array}{c}1.5463^{* * * *} \\
(22.5)\end{array}$ & $\begin{array}{c}1.0573^{* * *} \\
(10.9)\end{array}$ & $\begin{array}{c}0.1995^{* * *} \\
(23.1)\end{array}$ \\
\hline DEBT & $\begin{array}{c}-0.1522^{* * *} \\
(-16.7)\end{array}$ & $\begin{array}{c}-0.2101^{* * *} \\
(-9.20)\end{array}$ & $\begin{array}{c}-0.2323^{* * *} \\
(-9.07)\end{array}$ & $\begin{array}{c}-0.2949^{* * *} \\
(-8.17)\end{array}$ & $\begin{array}{c}-0.0366^{* * *} \\
(-11.4)\end{array}$ \\
\hline$R D$ & $\begin{array}{l}0.0338 \\
(0.68)\end{array}$ & $\begin{array}{c}-0.2775^{* * *} \\
(-2.98)\end{array}$ & $\begin{array}{c}1.1557^{* * *} \\
(11.3)\end{array}$ & $\begin{array}{c}-0.3186 \\
(-1.53)\end{array}$ & $\begin{array}{l}-0.0228 \\
(-1.55)\end{array}$ \\
\hline SALESG & $\begin{array}{c}0.0116^{* * * *} \\
(2.81)\end{array}$ & $\begin{array}{c}0.0201^{* * *} \\
(2.37)\end{array}$ & $\begin{array}{c}0.0124^{* * *} \\
(2.68)\end{array}$ & $\begin{array}{c}0.0210^{* * * *} \\
(2.77)\end{array}$ & $\begin{array}{c}0.0037^{* * *} \\
(2.86)\end{array}$ \\
\hline$D_{C S R} * N E W S$ & $\begin{array}{c}0.0000 \\
(0.00)\end{array}$ & $\begin{array}{c}-0.0017 \\
(-0.98)\end{array}$ & $\begin{array}{l}0.0027 \\
(0.47)\end{array}$ & $\begin{array}{l}0.0015 \\
(0.49)\end{array}$ & $\begin{array}{c}-0.0005 \\
(-1.25)\end{array}$ \\
\hline$D_{C S R} * I N C E N T I V E$ & $\begin{array}{l}0.0003 \\
(1.44)\end{array}$ & $\begin{array}{c}0.0009^{* * *} \\
(2.98)\end{array}$ & $\begin{array}{l}0.0002 \\
(0.50)\end{array}$ & $\begin{array}{l}0.0002 \\
(0.77)\end{array}$ & $\begin{array}{c}0.0001^{* *} \\
(2.10)\end{array}$ \\
\hline$D_{C S R} * P L E D G E$ & $\begin{array}{c}-0.1845^{* * *} \\
(-3.77)\end{array}$ & $\begin{array}{c}-0.3275^{* * *} \\
(-3.33)\end{array}$ & $\begin{array}{c}-0.2205^{* * *} \\
(-2.79)\end{array}$ & $\begin{array}{c}-0.2077^{* * *} \\
(-3.38)\end{array}$ & $\begin{array}{c}-0.0755^{* * * *} \\
(-3.92)\end{array}$ \\
\hline
\end{tabular}




\begin{tabular}{lrrrr}
\hline Num. of Obs. & 3,270 & 3,298 & 3,313 & 3,309 \\
Adj. R-square & 0.5396 & 0.2786 & 0.5834 & 0.1049 \\
\hline
\end{tabular}

Notes. This table reports pooled OLS estimation results of regression analysis of relating firm's financial performance measures to CSR and control factors. Explained variables are five firm's performance measures, ROA, ROE, ROS, OPERA and EPS. DCSR is a dummy which is equal to 1 if sample is CSR-firm, and 0 otherwise. Other control factors are ASSET, DEBT, RD, and SALESG. Three moderating variables between CSR and financial performance, $D_{C S R} * N E W S, D_{C S R} * I N C E N T I V E$ and $D_{C S R} * P L E D G E$ capture whether news exposure, CEO incentive compensation and directors and supervisors shareholdings pledge ratio are going to strengthen or weaken the effects of CSR on firm financial performance. For all five estimated regressions, estimated coefficients are under the specification that explained variable and explanatory variables of regression equation are contemporaneous. See Table 2 for the definition of variables. Yearly data is ranged from 2005 to 2009. The $t$-statistics (computed by White's heteroskedasticity-consistent standard errors) are shown in the parentheses below estimated coefficients, and $* * *, * *$ and $*$ denote that estimated coefficients reach $1 \%, 5 \%$ and $10 \%$ significantly level.

To sum up for estimated results of Table 5, doing CSR per se is going to bring about better performance. Higher incentive compensation and lower directors and supervisors shareholdings pledge ratio help to enhance the marginal effects of engaging in CSR on firm's performance. Conversely, news exposure cannot increase or decrease the marginal effects. Thus, incentive compensation is a positive moderator, directors and supervisors shareholdings pledge ratio is a negative moderator, and news exposure is not an evident one. In Table 5, regression estimations are under the specification that explained variables and explanatory variables are contemporaneous. Next, we want to specify that regression explained variables are in subsequent period relative to explained variables, and why we do so is trying to evade the problem of reverse causation among variables.

Table 6 reports pooled OLS estimation results of regression analysis of relating firm's five performance measures to CSR, control factors, and three cross-product terms, with the specification that explained variables are in subsequent period relative to explained variables. First, no matter which performance measure is used for explained variables, the estimated coefficient of CSR dummy is all positive, means that firm with CSR tends to perform well on these five measures. However, only when measures are ROA and EPS, the results are reaching statistical significance. Second, the estimated coefficient of cross product term of $D_{C S R}$ and NEWS are all positive but insignificant, means that no matter which performance is used, when a firm is CSR-firm, higher the frequency of news exposure will not affect performance. News exposure is still not a moderator between CSR and firm performance. Third, similar with the second, the estimated coefficient of cross product term of DCSR and INCENTIVE are all insignificantly (with marginal significance with ROE and EPS), CEO incentive compensation becomes an insignificant positive moderator here. Fourth, the estimated coefficient of cross product term of $D_{C S R}$ and $P L E D G E$ are still all significantly negative no matter which performance measure is used, means that higher directors and supervisors shareholdings pledge ratio deteriorates a firm's performance, conflict of interest hypothesis of Jensen and Ruback (1983) holds, and directors and supervisors shareholdings pledge ratio is a significant negative moderator between CSR and CFP. Finally, estimated coefficient for controls is similar with Table 5.

Table 6. Regression results of pooled estimation (explained variables are in subsequent period relative to explanatory variables)

\begin{tabular}{|c|c|c|c|c|c|}
\hline \multirow{2}{*}{$\begin{array}{l}\text { Explanatory } \\
\text { Variables }\end{array}$} & \multicolumn{5}{|c|}{ Explained Variables } \\
\hline & ROA & ROE & ROS & OPERA & $E P S$ \\
\hline \multirow{2}{*}{$D_{C S R}$} & $3.1503^{* *}$ & 3.9322 & 0.2407 & 1.8554 & $1.0772^{* *}$ \\
\hline & $(2.14)$ & $(1.43)$ & $(0.07)$ & $(0.83)$ & $(2.24)$ \\
\hline \multirow{2}{*}{ ASSET } & $0.7466^{* * *}$ & $0.8706^{* * *}$ & $1.4916^{* * *}$ & $0.8815^{* * *}$ & $0.1722^{* * *}$ \\
\hline & $(24.2)$ & $(13.6)$ & $(22.8)$ & $(9.41)$ & $(17.6)$ \\
\hline \multirow{2}{*}{$D E B T$} & $-0.1201^{* * *}$ & $-0.1504^{* * *}$ & $-0.2137^{* * *}$ & $-0.2402^{* * *}$ & $-0.0268^{* * *}$ \\
\hline & $(-11.9)$ & $(-6.02)$ & $(-8.88)$ & $(-6.52)$ & $(-7.59)$ \\
\hline \multirow{2}{*}{$R D$} & $0.1229^{* *}$ & -0.1327 & $1.2782^{* * *}$ & -0.0014 & -0.0055 \\
\hline & $(2.01)$ & $(-1.13)$ & $(11.2)$ & $(-0.01)$ & $(-0.32)$ \\
\hline \multirow{2}{*}{ SALESG } & $0.0062^{*}$ & $0.0176^{* *}$ & $0.0115^{* *}$ & 0.0054 & $0.0031^{* *}$ \\
\hline & $(1.86)$ & $(2.48)$ & $(2.48)$ & $(0.61)$ & $(2.38)$ \\
\hline \multirow{2}{*}{$D_{C S R} * N E W S$} & 0.0007 & 0.0020 & 0.0037 & 0.0019 & -0.0001 \\
\hline & $(0.23)$ & $(0.42)$ & $(0.51)$ & $(0.47)$ & $(-0.16)$ \\
\hline
\end{tabular}




\begin{tabular}{lccccc}
\hline $\boldsymbol{D}_{\text {CSR }}$ *INCENTIVE & 0.0002 & 0.0006 & 0.0001 & -0.00002 & 0.0001 \\
& $(0.59)$ & $(1.48)$ & $(0.14)$ & $(-0.06)$ & $(1.57)$ \\
$\boldsymbol{D}_{\text {CSR }}$ P PLEDGE & $-0.1989^{* * *}$ & $-0.4399^{* * *}$ & $-0.2584^{* *}$ & $-0.2163^{* * *}$ & $-0.0865^{* * *}$ \\
\hline Num. of Obs. & $(-3.14)$ & $(-2.60)$ & $(-2.14)$ & $(-3.19)$ & $(-3.85)$ \\
Adj. R-square & 2,606 & 2,628 & 2,639 & 2,635 & 2,616 \\
\hline
\end{tabular}

Notes. This table reports pooled OLS estimation results of regression analysis of relating firm's financial performance measures to CSR and control factors. Explained variables are five firm's performance measures, ROA, ROE, ROS, OPERA and EPS. $D_{C S R}$ is a dummy which is equal to 1 if sample is CSR-firm, and 0 otherwise. Other control factors are ASSET, DEBT, RD, and SALESG. Three moderating variables between CSR and financial performance, $D_{C S R} * N E W S, D_{C S R} * I N C E N T I V E$ and $D_{C S R} *$ PLEDGE capture whether news exposure, CEO incentive compensation and directors and supervisors shareholdings pledge ratio are going to strengthen or weaken the effects of CSR on firm financial performance. Under the consideration of reverse causation problem, for all five estimated regressions, estimated coefficients are under the specification that explained variable is in subsequent period relative to explanatory variables. See Table 2 for the definition of variables. Yearly data is ranged from 2005 to 2009. The $t$-statistics (computed by White's heteroskedasticity-consistent standard errors) are shown in the parentheses below estimated coefficients, and ${ }^{* *}, * *$ and $*$ denote that estimated coefficients reach $1 \%, 5 \%$ and $10 \%$ significantly level.

Because our data contains samples of firms and ranged from 2005-2009 and thus with time-series pattern, thus, we employ an one-period lag dependent variable to capture persistency in explained variable in each of five regressions. Table 7 reports pooled OLS estimation results of regression analysis of relating firm's five performance measures to CSR, control factors, and three cross-product terms and one-period lag dependent variable. While we have five performance measures and thus five explained variables, for all five estimated regressions, estimated coefficients in the left column are under the specification that explained variables and explanatory variables of regression equation are under the contemporaneous period, and estimated coefficients in the right column are under the specification that explained variable is in subsequent period relative to explanatory variables.

In Table 7, first, no matter which performance measure is used for explained variables, most of the estimated coefficients of CSR dummy are all positive but not significant, means although firm with CSR tends to perform well on these five measures, but their evidence do not reach statistical significance. Second, most of the estimated coefficient of cross product term of $D_{C S R}$ and NEWS are positive but insignificant, means that no matter which performance is used, when a firm is CSR-firm, higher the frequency of news exposure will not affect performance. News exposure is still not a significant positive moderator between CSR and firm performance. Third, three of ten estimated coefficients for cross product term of $D_{C S R}$ and INCENTIVE are significant (when performance variables are ROA, ROE and EPS, they are 0.0002, 0.0002 and 0.0001 , respectively), incentive compensation can partially play a significant positive moderator between CSR and FP. Fourth, the estimated coefficient of cross product term of $D_{C S R}$ and PLEDGE are still all significantly negative no matter which performance measure is used (except for under EPS, with marginal significance), means that CSR-firm with a higher directors and supervisors shareholdings pledge ratio deteriorates a firm's performance, and thus it is still a significant negative moderator between CSR and CFP. Finally, estimated coefficient for controls is similar with Table 5 and 6 , and estimated coefficients for lagged dependent variables are all significantly positive which represents that performance variables for firms have property of positive persistence (firm with better performance this year still performs well in next year, on average).

Table 7. Regression results of pooled estimation with lagged dependent variables

\begin{tabular}{|c|c|c|c|c|c|c|c|c|c|c|}
\hline \multirow{3}{*}{$\begin{array}{l}\text { Explanatory } \\
\text { Variables } \\
D_{C S R}\end{array}$} & \multicolumn{10}{|c|}{ Explained Variables } \\
\hline & \multicolumn{2}{|c|}{ ROA } & \multicolumn{2}{|c|}{$R O E$} & \multicolumn{2}{|c|}{ ROS } & \multicolumn{2}{|c|}{ OPERA } & \multicolumn{2}{|c|}{$E P S$} \\
\hline & $\begin{array}{c}0.7610 \\
(1.13)\end{array}$ & $\begin{array}{l}1.4095 \\
(1.51)\end{array}$ & $\begin{array}{l}1.4308 \\
(1.15)\end{array}$ & $\begin{array}{l}1.9025 \\
(0.84)\end{array}$ & $\begin{array}{c}0.0969 \\
(0.06)\end{array}$ & $\begin{array}{c}-0.3696 \\
(-0.33)\end{array}$ & $\begin{array}{l}1.6054 \\
(1.52)\end{array}$ & $\begin{array}{c}0.4262 \\
(0.46)\end{array}$ & $\begin{array}{c}0.0741 \\
(0.23)\end{array}$ & $\begin{array}{c}0.3222 \\
(0.80)\end{array}$ \\
\hline ASSET & $\begin{array}{c}0.2751^{* * *} \\
(11.9)\end{array}$ & $\begin{array}{c}0.1436^{* * * *} \\
(5.92)\end{array}$ & $\begin{array}{c}0.4545^{* * *} \\
(9.46)\end{array}$ & $\begin{array}{c}0.2364^{* * *} \\
(3.86)\end{array}$ & $\begin{array}{c}0.9160^{* * *} \\
(3.33)\end{array}$ & $\begin{array}{c}0.3854^{* * * *} \\
(3.89)\end{array}$ & $\begin{array}{c}0.5900^{* * *} \\
(3.31)\end{array}$ & $\begin{array}{c}0.1389 \\
(1.59)\end{array}$ & $\begin{array}{c}0.0623^{* * *} \\
(9.07)\end{array}$ & $\begin{array}{c}0.0255^{* * *} \\
(3.30)\end{array}$ \\
\hline$D E B T$ & $\begin{array}{c}-0.0560^{* * *} \\
(-8.02)\end{array}$ & $\begin{array}{c}-0.0106 \\
(-1.48)\end{array}$ & $\begin{array}{c}-0.0988^{* * *} \\
(-5.39)\end{array}$ & $\begin{array}{c}-0.0199 \\
(-0.88)\end{array}$ & $\begin{array}{c}-0.1487^{* * *} \\
(-2.73)\end{array}$ & $\begin{array}{c}-0.0485^{* *} \\
(-2.10)\end{array}$ & $\begin{array}{c}-0.1753^{* * *} \\
(-3.20)\end{array}$ & $\begin{array}{l}-0.0401 \\
(-1.33)\end{array}$ & $\begin{array}{c}-0.0128^{* * *} \\
(-5.11)\end{array}$ & $\begin{array}{c}0.0005 \\
(0.19)\end{array}$ \\
\hline$R D$ & $\begin{array}{c}-0.0672^{* *} \\
(-2.13)\end{array}$ & $\begin{array}{c}0.0681^{*} \\
(1.85)\end{array}$ & $\begin{array}{c}-0.2240^{* * *} \\
(-3.33)\end{array}$ & $\begin{array}{c}0.0122 \\
(0.15)\end{array}$ & $\begin{array}{c}0.6823^{* * *} \\
(3.86)\end{array}$ & $\begin{array}{c}0.4088^{* * *} \\
(4.76)\end{array}$ & $\begin{array}{c}-0.2932^{*} \\
(-1.91)\end{array}$ & $\begin{array}{c}0.0885 \\
(0.74)\end{array}$ & $\begin{array}{c}-0.0302^{* * *} \\
(-3.44)\end{array}$ & $\begin{array}{c}0.0045 \\
(0.44)\end{array}$ \\
\hline
\end{tabular}




\begin{tabular}{|c|c|c|c|c|c|c|c|c|c|c|}
\hline SALESG & $\begin{array}{c}0.0129^{* * *} \\
(3.41)\end{array}$ & $\begin{array}{l}-0.0014 \\
(-1.08)\end{array}$ & $\begin{array}{c}0.0270^{* * *} \\
(3.30)\end{array}$ & $\begin{array}{l}0.0078 \\
(1.42)\end{array}$ & $\begin{array}{r}0.0356^{*} \\
(1.94)\end{array}$ & $\begin{array}{l}0.0046 \\
(1.07)\end{array}$ & $\begin{array}{c}0.0768^{\text {*** }} \\
(4.50)\end{array}$ & $\begin{array}{c}-0.0070 \\
(-0.81)\end{array}$ & $\begin{array}{c}0.0039^{* * * *} \\
(3.84)\end{array}$ & $\begin{array}{l}0.0007 \\
(1.24)\end{array}$ \\
\hline$D_{C S R} * N E W S$ & $\begin{array}{c}0.0004 \\
(0.33)\end{array}$ & $\begin{array}{c}0.0008 \\
(0.46)\end{array}$ & $\begin{array}{c}-0.0004 \\
(-0.25)\end{array}$ & $\begin{array}{l}0.0027 \\
(0.65)\end{array}$ & $\begin{array}{c}0.0012 \\
(0.36)\end{array}$ & $\begin{array}{c}0.0015 \\
(0.66)\end{array}$ & $\begin{array}{r}0.0007 \\
(0.46)\end{array}$ & $\begin{array}{c}0.0006 \\
(0.42)\end{array}$ & $\begin{array}{c}-0.0001 \\
(-0.47)\end{array}$ & $\begin{array}{c}0.0001 \\
(0.21)\end{array}$ \\
\hline$D_{C S R} * I N C E N T I V E$ & $\begin{array}{r}0.0002^{*} \\
(1.94)\end{array}$ & $\begin{array}{l}0.0000 \\
(-0.22)\end{array}$ & $\begin{array}{c}0.0006^{* * *} \\
(2.64)\end{array}$ & $\begin{array}{l}0.0000 \\
(-0.01)\end{array}$ & $\begin{array}{l}0.0001 \\
(0.63)\end{array}$ & $\begin{array}{l}0.0000 \\
(-0.06)\end{array}$ & $\begin{array}{r}0.0001 \\
(0.67)\end{array}$ & $\begin{array}{c}-0.0001 \\
(-0.83)\end{array}$ & $\begin{array}{c}0.0001^{* * *} \\
(2.07)\end{array}$ & $\begin{array}{l}0.0000 \\
(-0.15)\end{array}$ \\
\hline$D_{C S R} * P L E D G E$ & $\begin{array}{c}-0.0583^{* *} \\
(-2.06)\end{array}$ & $\begin{array}{c}-0.0285 \\
(-0.66)\end{array}$ & $\begin{array}{c}-0.1375^{* *} \\
(-2.05)\end{array}$ & $\begin{array}{c}-0.1764 \\
(-1.13)\end{array}$ & $\begin{array}{c}-0.1211^{* *} \\
(-2.00)\end{array}$ & $\begin{array}{l}-0.0396 \\
(-0.88)\end{array}$ & $\begin{array}{c}-0.1017^{* *} \\
(-2.27)\end{array}$ & $\begin{array}{c}-0.0189 \\
(-0.53)\end{array}$ & $\begin{array}{c}-0.0196 \\
(-1.63)\end{array}$ & $\begin{array}{l}-0.0096 \\
(-0.54)\end{array}$ \\
\hline $\operatorname{LAG}(1)$ & $\begin{array}{c}0.6619^{* * *} \\
(38.3)\end{array}$ & $\begin{array}{c}0.6813^{* * *} \\
(35.6)\end{array}$ & $\begin{array}{c}0.5620^{* * *} \\
(23.5)\end{array}$ & $\begin{array}{c}0.5497^{* * *} \\
(17.0)\end{array}$ & $\begin{array}{c}0.4153^{* * * *} \\
(2.72)\end{array}$ & $\begin{array}{c}0.7102^{* * *} \\
(12.2)\end{array}$ & $\begin{array}{c}0.4431^{* * *} \\
(3.51)\end{array}$ & $\begin{array}{c}0.7058^{* * *} \\
(10.7)\end{array}$ & $\begin{array}{c}0.6954^{* * * *} \\
(35.1)\end{array}$ & $\begin{array}{c}0.6966^{* * *} \\
(30.8)\end{array}$ \\
\hline Num. of Obs. & 3,239 & 2,579 & 3,279 & 2,615 & 3,313 & 2,637 & 3,308 & 2,633 & 3,261 & 2,599 \\
\hline Adj. R-square & 0.7672 & 0.7510 & 0.5483 & 0.4919 & 0.7057 & 0.8039 & 0.3926 & 0.4769 & 0.6718 & 0.6519 \\
\hline
\end{tabular}

Notes. This table reports pooled OLS estimation results of regression analysis of relating firm's financial performance measures to CSR, control factors and one-period lag dependent variable $(L A G(1))$. Explained variables are five firm's performance measures, ROA, ROE, ROS, $O P E R A$ and $E P S . D_{C S R}$ is a dummy which is equal to 1 if sample is CSR-firm, and 0 otherwise. Other control factors are $A S S E T, D E B T, R D$, and SALESG. Three moderating variables between CSR and financial performance, $D_{C S R} * N E W S, D_{C S R} * I N C E N T I V E$ and $D_{C S R} * P L E D G E$ capture whether news exposure, CEO incentive compensation and directors and supervisors shareholdings pledge ratio are going to strengthen or weaken the effects of CSR on firm financial performance. For all five estimated regressions, estimated coefficients in the left column are under the specification that explained variable and explanatory variables of regression equation are contemporaneous, estimated coefficients in the right column are under the specification that explained variable is in subsequent period relative to explanatory variables. See Table 2 for the definition of variables. Yearly data is ranged from 2005 to 2009. The $t$-statistics (computed by White's heteroskedasticity-consistent standard errors) are shown in the parentheses below estimated coefficients, and***, ** and * denote that estimated coefficients reach $1 \%, 5 \%$ and $10 \%$ significantly level.

In this paper, our data contains samples of firms with years, we use fixed-effect estimation for our panel-form data. However, because a lot of firms lack enough samples to form balanced panel, estimation under fixed-effect versus random-effect model may have lower estimation efficiency. Table 8 reports fixed effect estimation results of regression analysis of relating firm's financial performance measures to CSR and control factors. To review, explained variables are five firm's performance measures, ROA, ROE, ROS, OPERA and EPS. $D_{C S R}$ is a dummy which is equal to 1 if sample is CSR-firm, and 0 otherwise. Other control factors are ASSET, DEBT, RD and SALESG. Three moderating variables between CSR and financial performance, $D_{C S R} * N E W S, D_{C S R} * I N C E N T I V E$ and $D_{C S R} *$ PLEDGE capture whether news exposure, CEO incentive compensation and directors and supervisors shareholdings pledge ratio are going to strengthen or weaken the effects of CSR on firm financial performance. For all five estimated regressions, estimated coefficients in the left column are under the specification that explained variable and explanatory variables of regression equation are contemporaneous, estimated coefficients in the right column are under the specification that explained variable is in subsequent period relative to explanatory variables.

In Table 8, first, to our surprise, most of the estimated coefficients of CSR dummy are negative and some of them are significant, means firm with CSR tends to perform worse on these five measures. Second, seven of ten estimated coefficient of cross product term of DCSR and NEWS are significantly positive, means that when a firm is CSR-firm, higher the frequency of news exposure will increase performance. News exposure here becomes a significant positive moderator between CSR and firm performance. Third, four of ten estimated coefficients for cross product term of $D_{C S} R$ and INCENTIVE are significant, means that when a firm is CSR-firm, higher incentive compensation will enhance performance, thus incentive compensation can partially play a significant positive moderating role. Fourth, some of the estimated coefficient of cross product term of $D_{C S R}$ and PLEDGE are significantly positive, represents when a firm is doing CSR, higher directors and supervisors shareholdings pledge ratio is going to increase a firm's performance, it plays a moderating role between CSR and CFP. Finally, estimated coefficient for controls is not also consistent with Table 5, 6, and 7.

To sum up for Table 8, under fixed-effect estimation, except for CEO incentive compensation, large parts of previous findings from Table 5, 6 and 7 are reverted in Table 8, however, because our data is unbalanced panel and exists variable that are not time-varying $\left(D_{C S R}\right)$, use of random-effect estimation may be better (R-squared is also largely reduced relative to pooled estimation in Table 5, 6, and 7). 
Table 8. Regression results with fixed effect estimation

\begin{tabular}{|c|c|c|c|c|c|c|c|c|c|c|}
\hline \multirow{3}{*}{$\begin{array}{l}\text { Explanatory } \\
\text { Variables } \\
D_{C S R}\end{array}$} & \multicolumn{10}{|c|}{ Explained Variables } \\
\hline & \multicolumn{2}{|c|}{ ROA } & \multicolumn{2}{|c|}{ ROE } & \multicolumn{2}{|c|}{ ROS } & \multicolumn{2}{|c|}{ OPERA } & \multicolumn{2}{|c|}{ EPS } \\
\hline & $\begin{array}{c}-4.3029^{* * * *} \\
(-4.03)\end{array}$ & $\begin{array}{c}-2.7597^{* *} \\
(-2.03)\end{array}$ & $\begin{array}{c}-7.5659^{* * *} \\
(-4.28)\end{array}$ & $\begin{array}{c}-4.9082 \\
(-1.53)\end{array}$ & $\begin{array}{c}-1.8478 \\
(-1.43)\end{array}$ & $\begin{array}{c}-3.2673^{* * *} \\
(-3.06)\end{array}$ & $\begin{array}{c}-1.2306 \\
(-0.91)\end{array}$ & $\begin{array}{c}-4.9943^{* * *} \\
(-2.84)\end{array}$ & $\begin{array}{c}-2.2067^{\text {*** }} \\
(-3.75)\end{array}$ & $\begin{array}{c}-1.5374^{* * *} \\
(-2.93)\end{array}$ \\
\hline ASSET & $\begin{array}{c}0.0262 \\
(0.04)\end{array}$ & $\begin{array}{c}-9.3134^{* * *} \\
(-11.7)\end{array}$ & $\begin{array}{c}3.2997^{* *} \\
(2.36)\end{array}$ & $\begin{array}{c}-16.118^{* * *} \\
(-9.05)\end{array}$ & $\begin{array}{c}3.4851^{*} \\
(1.70)\end{array}$ & $\begin{array}{c}-3.8537 \\
(-1.47)\end{array}$ & $\begin{array}{c}5.5401^{* * *} \\
(2.42)\end{array}$ & $\begin{array}{c}-1.1194 \\
(-0.31)\end{array}$ & $\begin{array}{c}1.1126^{* * *} \\
(5.92)\end{array}$ & $\begin{array}{c}-2.4252^{* * *} \\
(-9.13)\end{array}$ \\
\hline$D E B T$ & $\begin{array}{c}-0.1029^{* * *} \\
(-5.86)\end{array}$ & $\begin{array}{c}0.0896^{* * *} \\
(4.35)\end{array}$ & $\begin{array}{c}-0.2548^{* * *} \\
(-6.14)\end{array}$ & $\begin{array}{c}0.2496^{* * *} \\
(4.80)\end{array}$ & $\begin{array}{c}-0.0598 \\
(-0.74)\end{array}$ & $\begin{array}{c}0.0271 \\
(0.58)\end{array}$ & $\begin{array}{c}-0.1503 \\
(-1.58)\end{array}$ & $\begin{array}{c}0.0347 \\
(0.36)\end{array}$ & $\begin{array}{c}-0.0358^{* * *} \\
(-6.46)\end{array}$ & $\begin{array}{c}0.0328^{* * *} \\
(4.87)\end{array}$ \\
\hline$R D$ & $\begin{array}{c}-0.8591^{* * *} \\
(-7.00)\end{array}$ & $\begin{array}{c}-0.5228^{* * *} \\
(-4.36)\end{array}$ & $\begin{array}{c}-1.4405^{* * *} \\
(-7.40)\end{array}$ & $\begin{array}{c}-0.7742^{* * *} \\
(-2.94)\end{array}$ & $\begin{array}{c}0.1734 \\
(1.14)\end{array}$ & $\begin{array}{c}0.2788^{*} \\
(1.75)\end{array}$ & $\begin{array}{c}-2.1132^{* * *} \\
(-5.16)\end{array}$ & $\begin{array}{c}-1.0932 \\
(-1.62)\end{array}$ & $\begin{array}{c}-0.2009^{* * *} \\
(-6.48)\end{array}$ & $\begin{array}{c}-0.1540^{* * *} \\
(-3.71)\end{array}$ \\
\hline SALESG & $\begin{array}{c}0.0099^{* * *} \\
(3.73)\end{array}$ & $\begin{array}{c}0.0029 \\
(1.57)\end{array}$ & $\begin{array}{c}0.0176^{* * * *} \\
(2.89)\end{array}$ & $\begin{array}{c}0.0131^{* * *} \\
(2.60)\end{array}$ & $\begin{array}{c}0.0144^{*} \\
(1.66)\end{array}$ & $\begin{array}{c}0.0007 \\
(0.16)\end{array}$ & $\begin{array}{c}0.0435^{* * *} \\
(3.80)\end{array}$ & $\begin{array}{c}0.0202 \\
(1.52)\end{array}$ & $\begin{array}{c}0.0028^{* * *} \\
(3.48)\end{array}$ & $\begin{array}{c}0.0020^{* * * *} \\
(3.04)\end{array}$ \\
\hline$D_{C S R} * M E D I A$ & $\begin{array}{c}0.0018^{* *} \\
(2.47)\end{array}$ & $\begin{array}{c}0.0013^{* *} \\
(2.07)\end{array}$ & $\begin{array}{c}0.0036^{* *} \\
(2.28)\end{array}$ & $\begin{array}{c}0.0043^{*} \\
(1.88)\end{array}$ & $\begin{array}{c}0.0001 \\
(0.17)\end{array}$ & $\begin{array}{c}0.0015^{* *} \\
(2.22)\end{array}$ & $\begin{array}{c}0.0010 \\
(1.33)\end{array}$ & $\begin{array}{c}0.0004 \\
(0.56)\end{array}$ & $\begin{array}{c}0.0009^{* *} \\
(2.10)\end{array}$ & $\begin{array}{c}0.0010^{*} \\
(1.91)\end{array}$ \\
\hline$D_{C S R} * B O A R D$ & $\begin{array}{c}0.0004^{* * *} \\
(3.28)\end{array}$ & $\begin{array}{l}0.0001 \\
(0.62)\end{array}$ & $\begin{array}{c}0.0007^{* * *} \\
(3.33)\end{array}$ & $\begin{array}{c}-0.0001 \\
(-0.17)\end{array}$ & $\begin{array}{c}0.0003^{* *} \\
(2.41)\end{array}$ & $\begin{array}{l}-0.0001 \\
(-0.36)\end{array}$ & $\begin{array}{c}0.0002 \\
(1.27)\end{array}$ & $\begin{array}{c}-0.0002 \\
(-0.77)\end{array}$ & $\begin{array}{c}0.0002^{* * *} \\
(3.38)\end{array}$ & $\begin{array}{c}0.0001 \\
(0.85)\end{array}$ \\
\hline$D_{C S R} * P L E D G E$ & $\begin{array}{c}0.0260 \\
(0.89) \\
\end{array}$ & $\begin{array}{c}0.0830^{* *} \\
(2.12)\end{array}$ & $\begin{array}{r}0.0102 \\
(0.18) \\
\end{array}$ & $\begin{array}{r}0.1197 \\
(1.38) \\
\end{array}$ & $\begin{array}{r}-0.0021 \\
(-0.07) \\
\end{array}$ & $\begin{array}{c}0.1106^{* * *} \\
(3.38)\end{array}$ & $\begin{array}{c}-0.0280 \\
(-0.84)\end{array}$ & $\begin{array}{c}0.1660^{* * *} \\
(3.06)\end{array}$ & $\begin{array}{c}0.0094 \\
(0.98) \\
\end{array}$ & $\begin{array}{c}0.0332^{* *} \\
(2.45)\end{array}$ \\
\hline Num. of Obs. & 3,270 & 2,606 & 3,298 & 2,628 & 3,313 & 2,639 & 3,309 & 2,635 & 3,282 & 2,616 \\
\hline Adj. R-square & 0.1409 & 0.1454 & 0.1070 & 0.1186 & 0.0202 & 0.0092 & 0.1760 & 0.0314 & 0.1206 & 0.1212 \\
\hline
\end{tabular}

Notes. This table reports fixed effect estimation results of regression analysis of relating firm's financial performance measures to CSR and control factors. Explained variables are five firm's performance measures, ROA, ROE, ROS, OPERA and EPS. $D_{C S R}$ is a dummy which is equal to 1 if sample is CSR-firm, and 0 otherwise. Other control factors are ASSET, DEBT, RD, and SALESG. Three moderating variables between CSR and financial performance, $D_{C S R} * N E W S, D_{C S R} * I N C E N T I V E$ and $D_{C S R} *$ PLEDGE capture whether news exposure, CEO incentive compensation and directors and supervisors shareholdings pledge ratio are going to strengthen or weaken the effects of CSR on firm financial performance. For all five estimated regressions, estimated coefficients in the left column are under the specification that explained variable and explanatory variables of regression equation are contemporaneous, estimated coefficients in the right column are under the specification that explained variable is in subsequent period relative to explanatory variables. See Table 2 for the definition of variables. Yearly data is ranged from 2005 to 2009. The $t$-statistics (computed by White's heteroskedasticity-consistent standard errors) are shown in the parentheses below estimated coefficients, and $* * * * *$ and $*$ denote that estimated coefficients reach $1 \%, 5 \%$ and $10 \%$ significantly level.

Table 9 reports random effect estimation results of regression analysis of relating firm's financial performance measures to CSR, control factors and three cross-product terms. We observe that, first, most of estimated coefficients of CSR dummy are negative and some of them are still significant but the number is reduced, means firm with CSR tends to perform worse on returns on assets and earnings per share. Second, three of ten estimated coefficient on cross product term of $D_{C S R}$ and NEWS are significantly positive, means that when a firm is CSR-firm, higher the frequency of news exposure will increase these performance measures. News exposure here becomes a partial and significant positive moderator between CSR and firm performance. Third, three of ten estimated coefficients for cross product term of $D_{C S R}$ and INCENTIVE are significant, means that when a firm is CSR-firm, higher incentive compensation will enhance performance, thus CEO incentive compensation can still play a partially and significantly positive moderating role. Fourth, almost all of estimated coefficient of cross product term of $D_{C S R}$ and PLEDGE are negative, represents when a firm is doing CSR, higher directors and supervisors shareholdings pledge ratio is going to decrease a firm's performance. However, their evidence does not reach statistical significance level, it does not plays a moderating role between CSR and CFP. Finally, estimated coefficients for controls are more consistent with Table 5, 6, and 7, firm with larger assets, lower debt ratio and higher net sales growth rate tends to perform well. To sum up for Table 9, under random-effect estimation, some evidence shows news exposure plays a positive moderating role, CEO incentive compensation has positive moderating effects and pledge ratio has insignificant negative moderating effects. However, similar with fixed-effect estimation, relative to pooled estimation in Table 5, 6 and 7, adjusted R-squared is reduced. 
Table 9. Regression results with random effect estimation

\begin{tabular}{|c|c|c|c|c|c|c|c|c|c|c|}
\hline \multirow{3}{*}{$\begin{array}{l}\text { Explanatory } \\
\text { Variables } \\
\boldsymbol{D}_{C S R}\end{array}$} & \multicolumn{10}{|c|}{ Explained Variables } \\
\hline & \multicolumn{2}{|c|}{$R O A$} & \multicolumn{2}{|c|}{ ROE } & \multicolumn{2}{|c|}{ ROS } & \multicolumn{2}{|c|}{ OPERA } & \multicolumn{2}{|c|}{ EPS } \\
\hline & $\begin{array}{c}-1.9661^{*} \\
(-1.58)\end{array}$ & $\begin{array}{c}0.2180 \\
(0.14)\end{array}$ & $\begin{array}{l}-3.0243 \\
(-1.45)\end{array}$ & $\begin{array}{l}0.5299 \\
(0.18)\end{array}$ & $\begin{array}{l}-0.1939 \\
(-0.12)\end{array}$ & $\begin{array}{l}0.2085 \\
(0.10)\end{array}$ & $\begin{array}{c}-0.9748 \\
(-0.60)\end{array}$ & $\begin{array}{c}-1.4382 \\
(-0.75)\end{array}$ & $\begin{array}{c}-1.3320^{* *} \\
(-2.39)\end{array}$ & $\begin{array}{l}-0.3739 \\
(-0.62)\end{array}$ \\
\hline ASSET & $\begin{array}{c}0.8031^{* * *} \\
(3.57)\end{array}$ & $\begin{array}{c}-0.4984^{* *} \\
(-2.06)\end{array}$ & $\begin{array}{c}1.8012^{* * *} \\
(3.78)\end{array}$ & $\begin{array}{c}-0.4637 \\
(-0.94)\end{array}$ & $\begin{array}{c}0.0832 \\
(0.11)\end{array}$ & $\begin{array}{c}-1.6559^{* * *} \\
(-2.68)\end{array}$ & $\begin{array}{c}2.8024^{* *} \\
(2.54)\end{array}$ & $\begin{array}{l}1.0882 \\
(1.19)\end{array}$ & $\begin{array}{c}0.5154^{* * *} \\
(6.52)\end{array}$ & $\begin{array}{l}-0.1109 \\
(-1.30)\end{array}$ \\
\hline$D E B T$ & $\begin{array}{c}-0.1430^{* * *} \\
(-11.7)\end{array}$ & $\begin{array}{c}-0.0480^{* * *} \\
(-3.59)\end{array}$ & $\begin{array}{c}-0.2445^{* * * *} \\
(-7.51)\end{array}$ & $\begin{array}{c}-0.0374 \\
(-1.07)\end{array}$ & $\begin{array}{c}-0.1536^{* * *} \\
(-2.86)\end{array}$ & $\begin{array}{c}-0.1182^{* * *} \\
(-3.62)\end{array}$ & $\begin{array}{c}-0.2305^{* * *} \\
(-3.20)\end{array}$ & $\begin{array}{c}-0.1604^{* * *} \\
(-2.80)\end{array}$ & $\begin{array}{c}-0.0386^{* * *} \\
(-8.75)\end{array}$ & $\begin{array}{l}-0.0029 \\
(-0.60)\end{array}$ \\
\hline$R D$ & $\begin{array}{c}-0.4323^{* * *} \\
(-7.54)\end{array}$ & $\begin{array}{c}-0.0767 \\
(-0.98)\end{array}$ & $\begin{array}{c}-0.8324^{* * *} \\
(-7.74)\end{array}$ & $\begin{array}{c}-0.2676^{*} \\
(-1.65)\end{array}$ & $\begin{array}{c}0.5597^{* * *} \\
(4.59)\end{array}$ & $\begin{array}{c}0.7694^{* * *} \\
(5.97)\end{array}$ & $\begin{array}{c}-1.5858^{* * *} \\
(-4.23)\end{array}$ & $\begin{array}{c}-0.3146 \\
(-0.84)\end{array}$ & $\begin{array}{c}-0.1237^{* * *} \\
(-7.88)\end{array}$ & $\begin{array}{c}-0.0517^{* *} \\
(-2.39)\end{array}$ \\
\hline SALESG & $\begin{array}{c}0.0107^{* * *} \\
(3.33)\end{array}$ & $\begin{array}{r}0.0035^{*} \\
(1.79)\end{array}$ & $\begin{array}{c}0.0182^{* * *} \\
(2.69)\end{array}$ & $\begin{array}{c}0.0140^{* * * *} \\
(2.64)\end{array}$ & $\begin{array}{c}0.0142^{* *} \\
(2.26)\end{array}$ & $\begin{array}{c}0.0023 \\
(0.62)\end{array}$ & $\begin{array}{c}0.0422^{* * *} \\
(4.32)\end{array}$ & $\begin{array}{c}0.0167^{* *} \\
(2.17)\end{array}$ & $\begin{array}{c}0.0030^{* * *} \\
(3.48)\end{array}$ & $\begin{array}{c}0.0022^{* * *} \\
(2.62)\end{array}$ \\
\hline$D_{C S R} * N E W S$ & $\begin{array}{c}0.0015^{*} \\
(1.66)\end{array}$ & $\begin{array}{c}0.0017 \\
(1.49)\end{array}$ & $\begin{array}{c}0.0023 \\
(1.56)\end{array}$ & $\begin{array}{c}0.0043 \\
(1.53)\end{array}$ & $\begin{array}{c}0.0009 \\
(0.60)\end{array}$ & $\begin{array}{c}0.0026 \\
(1.26)\end{array}$ & $\begin{array}{c}0.0010 \\
(0.97)\end{array}$ & $\begin{array}{c}0.0012 \\
(0.94)\end{array}$ & $\begin{array}{c}0.0007^{* *} \\
(2.22)\end{array}$ & $\begin{array}{c}0.0010^{* *} \\
(2.56)\end{array}$ \\
\hline$D_{C S R} * I N C E N T I V E$ & $\begin{array}{c}0.0003^{* * *} \\
(2.39)\end{array}$ & $\begin{array}{c}0.0001 \\
(0.65)\end{array}$ & $\begin{array}{c}0.0008^{* * *} \\
(3.15)\end{array}$ & $\begin{array}{c}0.00003 \\
(0.09)\end{array}$ & $\begin{array}{c}0.0003 \\
(1.48)\end{array}$ & $\begin{array}{l}0.0000 \\
(-0.01)\end{array}$ & $\begin{array}{c}0.0002 \\
(1.14)\end{array}$ & $\begin{array}{c}-0.0002 \\
(-1.13)\end{array}$ & $\begin{array}{c}0.0001^{* * *} \\
(2.96)\end{array}$ & $\begin{array}{c}0.0001 \\
(0.99)\end{array}$ \\
\hline$D_{C S R} * P L E D G E$ & $\begin{array}{r}-0.0185 \\
(-0.50) \\
\end{array}$ & $\begin{array}{c}-0.0036 \\
(-0.07) \\
\end{array}$ & $\begin{array}{c}-0.1006 \\
(-1.16) \\
\end{array}$ & $\begin{array}{c}-0.0949 \\
(-0.83) \\
\end{array}$ & $\begin{array}{l}-0.0520 \\
(-1.35) \\
\end{array}$ & $\begin{array}{l}-0.0025 \\
(-0.04) \\
\end{array}$ & $\begin{array}{c}-0.0489 \\
(-1.42) \\
\end{array}$ & $\begin{array}{r}0.0057 \\
(0.11) \\
\end{array}$ & $\begin{array}{r}-0.0111 \\
(-0.82) \\
\end{array}$ & $\begin{array}{c}-0.0063 \\
(-0.37) \\
\end{array}$ \\
\hline Num. of Obs. & 3,270 & 2,606 & 3,298 & 2,628 & 3,313 & 2,639 & 3,309 & 2,635 & 3,282 & 2,616 \\
\hline Adj. R-square & 0.1163 & 0.0057 & 0.0987 & 0.0157 & 0.0105 & 0.0025 & 0.1685 & 0.0132 & 0.1082 & 0.0294 \\
\hline
\end{tabular}

Notes. This table reports random effect estimation results of regression analysis of relating firm's financial performance measures to CSR and control factors. Explained variables are five firm's performance measures, ROA, ROE, ROS, OPERA and EPS. $D_{C S R}$ is a dummy which is equal to 1 if sample is CSR-firm, and 0 otherwise. Other control factors are ASSET, DEBT, RD, and SALESG. Three moderating variables between CSR and financial performance, $D_{C S R} * N E W S, D_{C S R} * I N C E N T I V E$ and $D_{C S R} *$ PLEDGE capture whether news exposure, CEO incentive compensation and directors and supervisors shareholdings pledge ratio are going to strengthen or weaken the effects of CSR on firm financial performance. For all five estimated regressions, estimated coefficients in the left column are under the specification that explained variable and explanatory variables of regression equation are contemporaneous, estimated coefficients in the right column are under the specification that explained variable is in subsequent period relative to explanatory variables. See Table 2 for the definition of variables. Yearly data is ranged from 2005 to 2009. The $t$-statistics (computed by White's heteroskedasticity-consistent standard errors) are shown in the parentheses below estimated coefficients, and $* * * * *$ and $*$ denote that estimated coefficients reach $1 \%, 5 \%$ and $10 \%$ significantly level.

As mentioned before, because of possible sample selection bias due to non-random sampling of CSR-firms versus NonCSR-firms, Heckman (1979)'s two-stage is proposed to use for correction. Table 10 reports Heckman's two-stage estimation results of regression analysis. For all five regression estimation, the first stage is a probability model which determined sample is in CSR-firm or NonCSR-firm [use ASSET (natural log of current-period total assets), LDEBT (last-period debt ratio) and LPROFITL (last-period after-tax profits levels) as independent variables]. The second stage is then adds an inverse Mill's ratio to above mentioned regression equations. As before, for all five regression estimation results, estimated coefficients in the left column are all under the specification that explained variable and explanatory variables of regression equation are contemporaneous, estimated coefficients in the right column are all under the specification that explained variable is in subsequent period relative to explanatory variables.

For the estimated results of the first stage in Table 10, estimated of ASSET, LDEBT and LPROFITL are 0.5071, -0.0101 and 0.000 and all of them are statistically significant, means that firm with larger assets, lower debt ratio and lower after-tax profits levels is prone to be CSR-firm. After controlling this, we move our focus on estimation results on the second stage. We find that, first, most of estimated coefficients of CSR dummy are still negative and some of them are still significant, means doing CSR is related worse performance. Second, all of ten estimated coefficient of cross product term of $D_{C S R}$ and NEWS are positive but insignificant, means that when a firm is CSR-firm, higher the frequency of news exposure will increase these performance measures, but do not reach statistical significance. News exposure here is not an evident positive moderator. Third, all of estimated coefficients on cross product term of $D_{C S R}$ and INCENTIVE are positive and three of ten are significant (under performance measures are ROA, ROE and EPS, they are 0.0004, 0.0012 and 0.0002), implies that when a firm is CSR-firm, higher incentive compensation is inclined to increase performance, thus CEO incentive compensation 
still play a significantly positive moderating role. Fourth, all of estimated coefficient of cross product term of DCSR and PLEDGE are negative and seven of them reach statistical significance levels, represents when a firm is doing CSR, higher directors and supervisors shareholdings pledge ratio is going to decrease a firm's performance, it plays a negative moderating role between CSR and CFP. Finally, estimated coefficients for controls are more consistent with Table 5, 6, and 7, firm with larger assets, lower debt ratio and higher net sales growth rate tends to perform well. To sum up for Table 10, under Heckman (1979)'s two-stage estimation, incentive compensation has positive moderating effects and pledge ratio has significant negative moderating effects, which are more consistent with Table 5, 6 and 7 and as our most general results.

Table 10. Two-stage estimation result

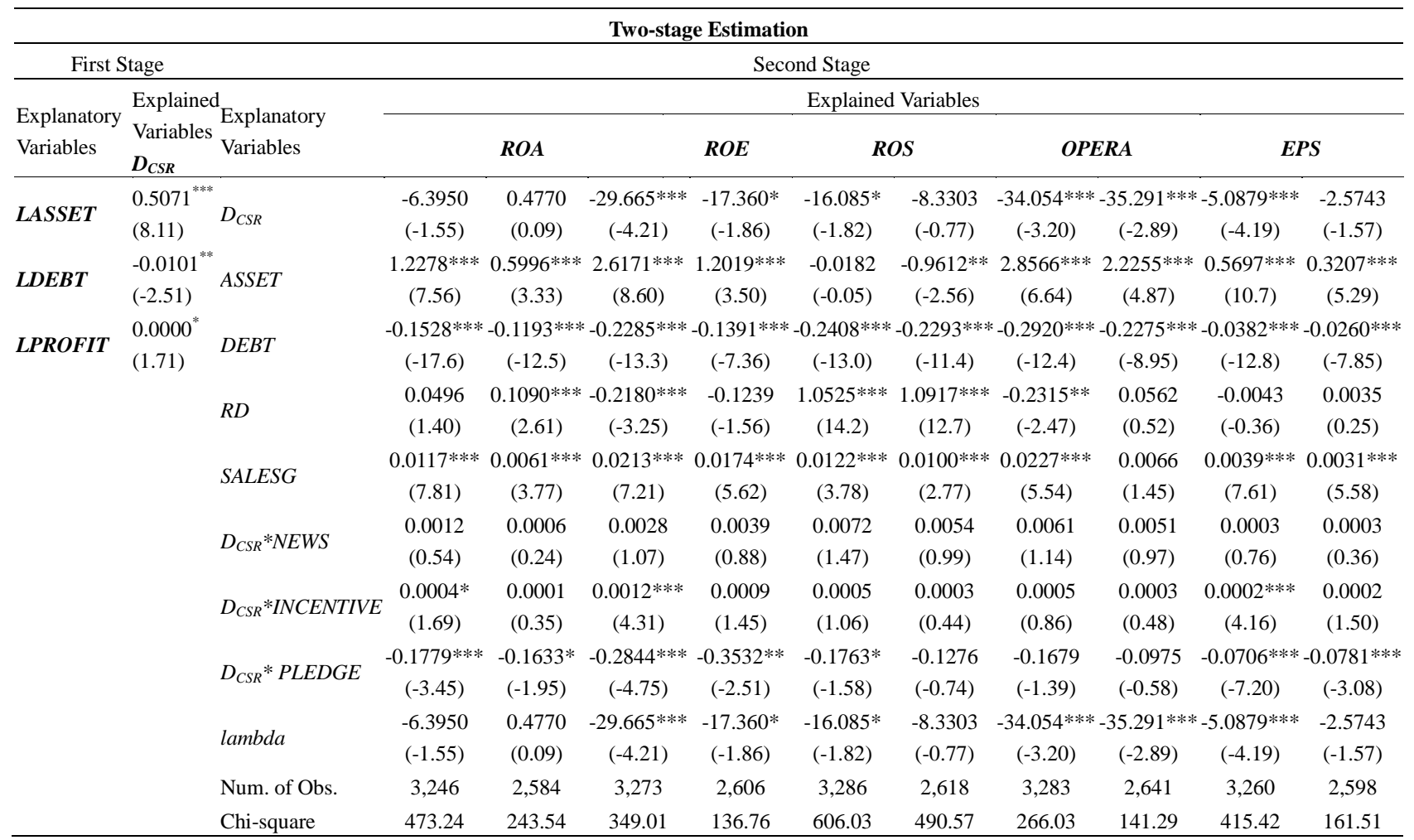

Notes. This table reports Heckman's two-stage estimation (in order to correct for sample selection bias) results of regression analysis of relating firm's financial performance measures to CSR and control factors. Explained variables are five firm's performance measures, $R O A$, $R O E, R O S, O P E R A$ and EPS. $D_{C S R}$ is a dummy which is equal to 1 if sample is CSR-firm, and 0 otherwise. Other control factors are ASSET, $D E B T, R D$ and SALESG. Three moderating variables between CSR and financial performance, $D_{C S R} * N E W S, D_{C S R} * I N C E N T I V E$ and $D_{C S R} * P L E D G E$ capture whether news exposure, CEO incentive compensation and directors and supervisors shareholdings pledge ratio are going to strengthen or weaken the effects of CSR on firm financial performance. For all five regression estimation, the first stage is a probability model which determined sample is in CSR-firm or NonCSR-firm [use ASSET (current-period total assets), LDEBT (last-period debt ratio) and LPROFIT (last-period after-tax profits) as independent variables]. The second stage is then adds an inverse Mill's ratio to above mentioned regression equations. For all five regression estimation results, estimated coefficients in the left column are all under the specification that explained variable and explanatory variables of regression equation are contemporaneous, estimated coefficients in the right column are all under the specification that explained variable is in subsequent period relative to explanatory variables. See Table 2 for the definition of variables. Yearly data is ranged from 2005 to 2009. The $z$-statistics are shown in the parentheses below estimated coefficients, and ${ }^{* * *}, * *$ and $*$ denote that estimated coefficients reach $1 \%, 5 \%$ and $10 \%$ significantly level.

We employ another technique to correct for sample selection bias, Rosenbaum and Rubin (1983, 1985a,b)' PSM. It's first step is to estimate the probability model [Similar with Heckman (1979)'s two-stage estimation, we use ASSET (natural log of current-period total assets), LDEBT (last-period debt ratio) and LPROFITL (last-period after-tax profits levels) as independent variables] which describes samples are selected as CSR-firms or NonCSR-firms. Then, for each firm in the samples of CSR-firms, firms in NonCSR-firms are selected as matched samples according to the closeness of the above estimated probability (propensity scores). The drawback of using PSM is that after-matching samples will be substantially reduced. See Shen and Chang (2009) 
for detail.

Based on after-matching samples, table 11 reports OLS estimation results of regression analysis of relating firm's financial performance measures to CSR, control factors and three cross-product terms. We observe that, first and interestingly, all of estimated coefficients of CSR dummy are positive and significant, implies that doing CSR is related to performing well. Second, all of ten estimated coefficient on cross product term of $D_{C S R}$ and NEWS are not significant and mixed with positive and negative signs, means that when a firm is CSR-firm, higher the frequency of news exposure will not have impacts on performance. News exposure has no moderating effects, it is neutral. Third, almost all of estimated coefficients on cross product term of $D_{C S R}$ and INCENTIVE are positive and two of ten are significant (under performance measures are ROE and EPS, they are 0.0008 and 0.0001 , respectively), implies that when a firm is CSR-firm, higher incentive compensation clines toward better performance, thus incentive compensation still play a partially and significantly positive moderating role.

Fourth, remain interesting, all of estimated coefficient of cross product term of $D_{C S R}$ and PLEDGE are negative and significant which represents that when a firm is doing CSR, higher directors and supervisors shareholdings pledge ratio is going to decrease a firm's performance, thus it plays a significantly negative moderating role between CSR and CFP. The conflict of interest hypothesis of Jensen and Ruback (1983) holds. Finally, estimated coefficients for controls are more consistent with Table 5, 6,7 and 10, firm with larger assets, lower debt ratio and higher net sales growth rate has a tendency to behave well. To sum up for Table 11, even using propensity score sample matching method of Rosenbaum and Rubin $(1983,1985 \mathrm{a}, \mathrm{b})$ to correct for sample selection bias, doing CSR is related to better performance, CEO incentive compensation has positive moderating effects and pledge ratio has significant negative moderating effects and news exposure are an evident one. These findings are more consistent with Table 5, 6,7 and 10 and serves as our general results.

Table 11. Regression results with use of propensity score sample matching

\begin{tabular}{|c|c|c|c|c|c|c|c|c|c|c|}
\hline \multirow{3}{*}{$\begin{array}{l}\text { Explanatory } \\
\text { Variables } \\
D_{C S R}\end{array}$} & \multicolumn{10}{|c|}{ Explained Variables } \\
\hline & \multicolumn{2}{|c|}{ ROA } & \multicolumn{2}{|c|}{$R O E$} & \multicolumn{2}{|c|}{ ROS } & \multicolumn{2}{|c|}{ OPERA } & \multicolumn{2}{|c|}{ EPS } \\
\hline & $\begin{array}{c}4.4634^{* * *} \\
(3.25)\end{array}$ & $\begin{array}{c}7.2687^{\text {*** }} \\
(3.95)\end{array}$ & $\begin{array}{c}7.5160^{* * * *} \\
(3.24)\end{array}$ & $\begin{array}{c}9.6881^{* * * *} \\
(2.98)\end{array}$ & $\begin{array}{c}7.9446^{* * *} \\
(2.67)\end{array}$ & $\begin{array}{c}11.954^{* * *} \\
(2.86)\end{array}$ & $\begin{array}{c}4.9103^{* *} \\
(2.19)\end{array}$ & $\begin{array}{c}10.021^{* * *} \\
(3.01)\end{array}$ & $\begin{array}{c}1.4324^{\text {*** }} \\
(2.76)\end{array}$ & $\begin{array}{c}2.1116^{* * * *} \\
(3.26)\end{array}$ \\
\hline ASSET & $\begin{array}{c}0.5767^{* * *} \\
(5.16)\end{array}$ & $\begin{array}{c}0.5124^{* * *} \\
(3.51)\end{array}$ & $\begin{array}{c}0.6035^{* * *} \\
(3.95)\end{array}$ & $\begin{array}{c}0.5031^{*} \\
(1.76)\end{array}$ & $\begin{array}{c}1.0279^{* * *} \\
(4.58)\end{array}$ & $\begin{array}{c}0.8409^{* * * *} \\
(3.10)\end{array}$ & $\begin{array}{c}0.7065^{* * *} \\
(4.12)\end{array}$ & $\begin{array}{c}0.4861^{* *} \\
(2.24)\end{array}$ & $\begin{array}{c}0.2343^{* * *} \\
(5.18)\end{array}$ & $\begin{array}{c}0.1895^{* * *} \\
(3.51)\end{array}$ \\
\hline$D E B T$ & $\begin{array}{c}-0.0870^{* *} \\
(-2.30)\end{array}$ & $\begin{array}{c}-0.1047^{* *} \\
(-1.99)\end{array}$ & $\begin{array}{c}-0.1027 \\
(-1.63)\end{array}$ & $\begin{array}{c}-0.1513 \\
(-1.13)\end{array}$ & $\begin{array}{c}-0.1675^{* *} \\
(-2.00)\end{array}$ & $\begin{array}{c}-0.1545 \\
(-1.36)\end{array}$ & $\begin{array}{c}-0.2274^{* * *} \\
(-3.62)\end{array}$ & $\begin{array}{c}-0.2294^{* *} \\
(-2.45)\end{array}$ & $\begin{array}{c}-0.0561^{* * *} \\
(-3.25)\end{array}$ & $\begin{array}{c}-0.0513^{* *} \\
(-2.30)\end{array}$ \\
\hline$R D$ & $\begin{array}{c}0.2521^{*} \\
(1.71)\end{array}$ & $\begin{array}{c}0.0986 \\
(0.33)\end{array}$ & $\begin{array}{c}0.0643 \\
(0.30)\end{array}$ & $\begin{array}{c}0.3209 \\
(1.12)\end{array}$ & $\begin{array}{c}0.8448^{* * *} \\
(2.97)\end{array}$ & $\begin{array}{c}0.6608 \\
(1.10)\end{array}$ & $\begin{array}{c}0.0350 \\
(0.15)\end{array}$ & $\begin{array}{c}-0.2923 \\
(-0.52)\end{array}$ & $\begin{array}{c}-0.0886 \\
(-1.37)\end{array}$ & $\begin{array}{c}-0.0833 \\
(-1.01)\end{array}$ \\
\hline SALESG & $\begin{array}{c}0.0984^{* * *} \\
(3.31)\end{array}$ & $\begin{array}{c}0.1372^{* * *} \\
(3.05)\end{array}$ & $\begin{array}{c}0.1783^{* * *} \\
(3.83)\end{array}$ & $\begin{array}{c}0.2350^{* * * *} \\
(3.84)\end{array}$ & $\begin{array}{c}0.1117^{* *} \\
(2.00)\end{array}$ & $\begin{array}{c}0.1695^{* *} \\
(1.98)\end{array}$ & $\begin{array}{c}0.1379^{* * *} \\
(2.72)\end{array}$ & $\begin{array}{c}0.1920^{* * *} \\
(2.59)\end{array}$ & $\begin{array}{c}0.0295^{* * *} \\
(3.34)\end{array}$ & $\begin{array}{c}0.0516^{* * *} \\
(4.53)\end{array}$ \\
\hline$D_{C S R} * N E W S$ & $\begin{array}{c}0.0006 \\
(0.37)\end{array}$ & $\begin{array}{c}0.0011 \\
(0.39)\end{array}$ & $\begin{array}{l}-0.0007 \\
(-0.47)\end{array}$ & $\begin{array}{c}0.0026 \\
(0.56)\end{array}$ & $\begin{array}{c}0.0036 \\
(0.61)\end{array}$ & $\begin{array}{c}0.0047 \\
(0.64)\end{array}$ & $\begin{array}{c}0.0021 \\
(0.68)\end{array}$ & $\begin{array}{c}0.0025 \\
(0.62)\end{array}$ & $\begin{array}{c}-0.0007 \\
(-1.33)\end{array}$ & $\begin{array}{c}-0.0002 \\
(-0.48)\end{array}$ \\
\hline$D_{C S R} * I N C E N T I V E$ & $\begin{array}{c}0.0002 \\
(1.07)\end{array}$ & $\begin{array}{c}0.0000 \\
(0.00)\end{array}$ & $\begin{array}{c}0.0008^{* * *} \\
(2.61)\end{array}$ & $\begin{array}{c}0.0004 \\
(0.94)\end{array}$ & $\begin{array}{l}0.0001 \\
(0.34)\end{array}$ & $\begin{array}{r}-0.0001 \\
(-0.24)\end{array}$ & $\begin{array}{l}0.0001 \\
(0.37)\end{array}$ & $\begin{array}{c}-0.0003 \\
(-0.91)\end{array}$ & $\begin{array}{c}0.0001^{*} \\
(1.89)\end{array}$ & $\begin{array}{l}0.0001 \\
(0.89)\end{array}$ \\
\hline$D_{C S R} * P L E D G E$ & $\begin{array}{c}-0.1785^{* * *} \\
(-3.80)\end{array}$ & $\begin{array}{c}-0.1877^{* *} \\
(-2.53)\end{array}$ & $\begin{array}{c}-0.3085^{* * *} \\
(-3.34)\end{array}$ & $\begin{array}{c}-0.4305^{* *} \\
(-2.55)\end{array}$ & $\begin{array}{c}-0.2000^{* * *} \\
(-2.67)\end{array}$ & $\begin{array}{c}-0.2278^{*} \\
(-1.92)\end{array}$ & $\begin{array}{c}-0.1964^{* * *} \\
(-3.53)\end{array}$ & $\begin{array}{c}-0.1915^{* * *} \\
(-2.61)\end{array}$ & $\begin{array}{c}-0.0692^{* * *} \\
(-3.49)\end{array}$ & $\begin{array}{c}-0.0794^{* * *} \\
(-3.28)\end{array}$ \\
\hline Num. of Obs. & 139 & 104 & 139 & 103 & 140 & 104 & 140 & 104 & 137 & 102 \\
\hline Adj. R-square & 0.7290 & 0.6420 & 0.6159 & 0.4146 & 0.6672 & 0.5911 & 0.4046 & 0.3002 & 0.5784 & 0.5013 \\
\hline
\end{tabular}

Notes. Using Rosenbaum and Rubin (1983, 1985a,b)'s Propensity Score Matching (PSM) to correct for sample selection bias [matching variable are ASSET (current-period total assets), LDEBT (last-period debt ratio) and LPROFIT (last-period after-tax profits)], this table reports OLS estimation results of regression analysis of relating firm's financial performance measures to CSR and control factors. Explained variables are five firm's performance measures, ROA, ROE, ROS, OPERA and EPS. $D_{C S R}$ is a dummy which is equal to 1 if sample is CSR-firm, and 0 otherwise. Other control factors are ASSET, DEBT, RD and SALESG. Three moderating variables between CSR and financial performance, $D_{C S R} * N E W S, D_{C S R}{ }^{*} I N C E N T I V E$ and $D_{C S R} * P L E D G E$ capture whether news exposure, CEO incentive compensation and directors and supervisors shareholdings pledge ratio are going to strengthen or weaken the effects of CSR on firm financial performance. For all regression estimation results, estimated coefficients in the left column are all under the specification that explained variable and explanatory variables of regression equation are contemporaneous, estimated coefficients in the right column are all under the specification that explained variable is in subsequent period relative to explanatory variables. Yearly data is ranged from 2005 to 2009 . The $t$-statistics (computed by White's heteroskedasticity-consistent standard errors) are shown in the parentheses below estimated coefficients, and ${ }^{* * *},{ }^{* *}$ and $*$ denote that estimated coefficients reach $1 \%, 5 \%$ and $10 \%$ significantly level. 
As a whole, our empirical results generally show that firm with CSR will bring about better accounting financial performance. Thus, being socially responsible firm will have positive feedback on performance. Our evidence also generally shows that there exist two evident positive moderating variables which have effects on the magnitude for doing CSR on financial performance. Incentive compensation has positive moderating effects and pledge ratio has significant negative moderating effect and these are two points favoring our previous proposition. However, our inference that news exposure might be a moderator does not receive supports from the analysis. At the same time, our analyzing results are generally consistent under various robustness checks.

For management implication, news exposure cannot bring additional and positive marginal effects of doing good things. It might because interesting stakeholders do not understanding what are your doing and the possible advantages they can obtain. Given a firm's stakeholders or the general public have the property of other-regarding (they care somethings other than making money of a firm), the key is to let news exposure describe clearly about which firm is doing CSR and what's the benefits for our society or for specific group. Striking for news exposure which really reports CSR engagement/contribution might works for increasing firm performance.

However, philanthropic behaviors for a firm need to take care of social impression and reactions among various cultures in different countries. In some countries, giving relief to some persons in need sometimes receives many thanks, but in some country, giving relief needs to be low profile in order to take care of ways of giving to protect dignity for persons in need. For example, recently, a Chinese entrepreneur comes to Taiwan for charitable donations. However, at the outset, because of his high profile (to show his money on the news), he receives some positive but more negative media reports because his behavior sometime let people in need lose faces and dignities. The Chinese Buddhist has also said that help others, but not for a specific purpose, and not hold for a mind with a pity for the people in need, then the merits and good fortunes would be the greatest.

Specifically, through this paper, we are immersing in the current trend of recent development of empirical analysis of CSR and FP, which advocating that there are many moderators and mediators between CSR and FP and thus should be considered and examined in the model to get a clear picture about the mechanism between firm's social behaviors and their consequences on performance (McWilliams \& Siegel, 2000; Orlitzky, Schmidt, \& Rynes, 2003; Margolis \& Walsh, 2003, Rowley \& Berman, 2000, Surroca, Tribo, \& Waddock, 2010). For example, Luchs, Rebecca, Naylor, Irwin, and Raghunathan (2007) found that consumer's perception of effectiveness for ethical products is moderated by the degree of their believing about the importance of ethical issues. Our research propose and examine that whether news exposure, CEO incentive compensation and directors and supervisors' shareholdings pledge ratio are moderators for the relationship between CSR and CFP.

\section{Conclusion and Implication}

The empirical literature about the relationship about corporate social responsibility financial performance is well-document but not reach a consensus. Some of them got positive relation, part of them showed negative linkage and part of them showed neutral or nonlinear related. McWilliams and Siegel (2000), Orlitzky, Schmidt and Rynes (2003) proposed that if empirical model for CSR and FP lack of important control variables for firm performance, the model will suffer from mis-specification problem. Margolis and Walsh (2003) stressed the importance of developing models that incorporate omitted variables, test mediating mechanisms and contextual conditions, and establish causal links between social and financial performance. Rowley and Berman (2000) also proposed that there are many possible moderators" and mediators between CSR and FP and thus should be considered in the research model for CSR and FP. Based on this literature development mentioned, this paper proposes and examines the existence of moderator between CSR and FP.

We use a newly developed database, called the Management System for News and Knowledge to collect frequency of news exposure of TWSE-listed companies and relate them to the relationship between CSR and firm financial performance. We also incorporate two moderators, incentive compensation and directors and supervisors' shareholdings pledge ratio between CSR and CFP into the analysis. Based on the data 2005 2009, regression results show that being CSR firm will have a superior performance, higher incentive compensation will enhance the marginal effects of doing CSR on performance, higher directors and supervisors' shareholdings pledge ratio will deteriorate the marginal effects of doing CSR on performance, and news exposure has little and insignificant influence on marginal effects of CSR on CFP. Thus, incentive is a significantly positive moderator, directors and supervisors' shareholdings pledge ratio is a significantly negative moderator, and news exposure is an evident one, for the relationship between corporate social responsibility and firm's financial performance.

For the future research, first, the definition of news exposure is limited to newspapers, analysis under other forms of media coverage could be added. Second, now we use all positive and negative news as our definition of 
news exposure, however, separation between positive and negative news and incorporate into analysis makes this trend of research be plentiful. Third, in practice, CEO incentive compensation includes short-term tool such as cash bonus and long-term tool such as stock option, and future research could contain these different settings. Fourth, now we only employ five-year data for analysis, so lengthening the data is needed to investigate the short-run and long-run effects of doing CSR and possible roles for moderating variables could play. Fifth, in this paper, the measurement of firm's CSR activities is now using 0 or 1 classification by a dummy variable, it has the risk of too arbitrary and thus need employ continuous ratings in the future. Finally, other possible moderator between CSR and CFP such as stakeholder's characteristics or industrial characteristics are also interesting and thus deserves be analyzed.

\section{Acknowledgments}

The author would like to thank the anonymous reviewers for helpful and constructive comments that contributed to improving the final version of the paper. All remaining errors are my own.

\section{References}

Aldag, R. J., \& Bartol, K. M. (1978). Empirical Studies of Corporate Social Performance and Policy: A Survey of Problems and Results. Research in Corporate Social Performance and Policy, 1, 165-199.

Amihud, Y., \& Lev, B. (1981). Risk Reduction as a Managerial Motive for Conglomerate Mergers. Bell Journal of Economics, 12, 605-617. http://dx.doi.org/10.2307/3003575

Anginer, D., Fisher, K. L., \& Statman, M. (2008). Stocks of Admired Companies and Despised Ones. Manuscript.

Arlow, P., \& Gannon, M. J. (1982). Social Responsiveness, Corporate Structure, and Economic Performance. Academy of Management Review, 7, 235-241. http://dx.doi.org/10.2307/257302

Aupperle, K., Carroll, A., \& Hatfield, J. (1985). An Empirical Examination of the Relationship between Corporate Social Responsibility and Profitability. Academy of Management Journal, 28, 446-463. http://dx.doi.org/10.2307/256210

Barnett, M. L., \& Salomon, R. M. (2006). Beyond Dichotomy: The Curvilinear Relationship between Social Responsibility and Financial Performance. Strategic Management Journal, 27, 1101-1122. http://dx.doi.org/10.1002/smj.557

Barney, J. B. (1991). Firm Resources and Sustained Competitive Advantage. Journal of Management, 17, 99-120. http://dx.doi.org/10.1177/014920639101700108

Bragdon, J., \& Marlin, J. (1972). Is Pollution Profitable? Risk Management, 19, 9-18.

Brammer, S., Brooks, C., \& Pavelin, S. (2006). Corporate Social Performance and Stock Returns: UK Evidence from Disaggregate Measures. Financial Management, 35, 97-116. http://dx.doi.org/10.1111/j.1755-053X.2006.tb00149.x

Chang, Y. (2009). Corporate Social Responsibility and Financial Performance-Empirical Evidence from Taiwan. Review of Social Sciences, 3, 57-120.

Chang, Y. (2011). Do Companies with Corporate Social Responsibility Perform Better in Stock Returns? Fu Jen Management Review, 18, 79-118.

Chang, Y., \& Shen, C. H. (2011). Is Corporate Soical Responsibility Rewarded by the Cost of Debt-Credit Ratings View. Manuscript.

Chen, K. H., \& Metcalf, R. W. (1980). The Relationship Between Pollution Control Record and Financial Indicators Revisited. The Accounting Review, 55, 168-177.

Chih, H. L., Chih, H. H., \& Chou, P. H. (2010). Being Good or Being Known: Corporate Governance, Media Coverage, and Earnings Announcements. Service Industries Journal, forthcoming. http://dx.doi.org/10.1080/02642060802236152

Cochran, P. L., \& Wood, R. A. (1984). Corporate Social Responsibility and Financial Performance. Academy of Management Journal, 27, 42-56. http://dx.doi.org/10.2307/255956

Cornell, B., \& Shapiro, A. C. (1987). Corporate Stakeholder and Corporate Finance. Financial Management, 16, 5-14. http://dx.doi.org/10.2307/3665543

Deephouse, D. L. (2000). Media Reputation as a Strategic Resource: An Integration of Mass Communication and Resource-Based

Theories.

Journal of

Management,

26 ,

1091-1112. 
http://dx.doi.org/10.1177/014920630002600602

Deephouse, D. L. (2003). Stakeholder Knowledge of Corporate Citizenship: Integrating Reputation into the CSP/CFP Debate. Presented at the Annual Meeting of the Academy of Management, Seattle, WA. August 5.

Fan, P. H., \& Wong, T. J. (2002). Corporate Ownership Structure and the Information of Accounting Earnings in East Asia. Journal of Accounting and Economics, 33, 401-425. http://dx.doi.org/10.1016/S0165-4101(02)00047-2

Folger, H. R., \& Nutt, F. (1975). A Note on Social Responsibility and Stock Valuation. Academy of Management Journal, 18, 155-160. http://dx.doi.org/10.2307/255635

Fombrun, C., \& Shanley, M. (1990). What's in a Name? Reputation Building and Corporate Strategy. Academy of Management Journal, 33, 233-258. http://dx.doi.org/10.2307/256324

Freeman, R. E. (1984). Strategic Management: A stakeholder Approach. Massachusetts: Pitman Publishing Inc.

Friedman, M. (1970). The Social Responsibility of Business Is To Increase Its Profits. The New York Times Magazine, (33), 122-126.

Friedman, M., \& Friedman, R. (1981). Free to Choose. Avon, New York: NY.

Gaines-Ross, L. (2000). CEO Reputation: A Key Factor in Shareholder Value. Corporate Reputation Review, 3, 366-370. http://dx.doi.org/10.1057/palgrave.crr.1540127

Griffin, J. J., \& Mahon, J. F. (1997). The Corporate Social Performance and Corporate Financial Performance Debate: Twenty-five Years of Incomparable Research. Business and Society, 36, 5-31. http://dx.doi.org/10.1177/000765039703600102

Hall, R. (1992). The Strategic Analysis of Intangible Resources. Strategic Management Journal, 13, 135-144. http://dx.doi.org/10.1002/smj.4250130205

Heckman, J. (1979). Sample Selection Bias as a Specification Error. Econometrica, 47, 153-162. http://dx.doi.org/10.2307/1912352

Heinz, D. C.(1976). Financial Correlates of a Social Measure. Akron Business and Economic Review, 7, 48-51.

Herremans, I., Akathaporn, P., \& McInnes, M. (1993). An Investigation of Corporate Social Responsibility Reputation and Economic Performance. Accounting, Organisations and Society, 18, 587-604. http://dx.doi.org/10.1016/0361-3682(93)90044-7

Holmstrom, B. (1979). Moral Hazard and Observability. Bell Journal of Economics, 10, 74-91. http://dx.doi.org/10.2307/3003320

Hudson, C., Jahera, J., \& Lloyd, W. (1992). Further Evidence on the Relationship between Ownership and Performance. The Financial Review, 27, 227-239. http://dx.doi.org/10.1111/j.1540-6288.1992.tb01315.x

Jensen, M. C., \& Meckling, W. H. (1976). Theory of the Firm: Managerial Behavior, Agency Cost and Ownership Structure. Journal of Financial Economics, 3, 305-360. http://dx.doi.org/10.1016/0304-405X(76)90026-X

Jensen, M. C., \& Ruback, R. (1983). The Market of Corporate Control: The Scientific Evidence. Journal of Financial Economics, 11, 5-50. http://dx.doi.org/10.1016/0304-405X(83)90004-1

Kesner, I. F. (1987). Directors Stock Ownership and Organization Performance: An Investigation of Fortune 500 Companies. Journal of Management, 13, 499-507. http://dx.doi.org/10.1177/014920638701300306

King, A., \& Lenox, M. (2002). Exploring the Locus of Profitable Pollution Reduction. Management Science, 48, 289-299. http://dx.doi.org/10.1287/mnsc.48.2.289.258

Leland, H., \& Pyle, D. (1977). Informational Asymmetries, Financial Structure, and Financial Intermediation. Journal of Finance, 32, 371-388. http://dx.doi.org/10.2307/2326770

Mahapatra, S. (1984). Investor Reaction to a Corporate Social Accounting. Journal of Business Finance and Accounting, 11, 29-40. http://dx.doi.org/10.1111/j.1468-5957.1984.tb00054.x

Mahoney, L. S., \& Thorne, L. (2005). Corporate Social Responsibility and Long-term Compensation: Evidence from Canada. Journal of Business Ethics, 57, 241-253. http://dx.doi.org/10.1007/s10551-004-5367-z

Mahoney, L. S., \& Thorne, L. (2006). An Examination of the Structure of Executive Compensation and Corporate Social Responsibility: A Canadian Investigation. Journal of Business Ethics, 69, 149-162. http://dx.doi.org/10.1007/s10551-006-9073-x 
Marens, R. (2002). Investing Corporate Governance: The Mid-Century Emergence of Shareholder Activism. Journal of Business and Management, 8, 365-389.

Margolis, J., \& Walsh, J. (2003). Misery Loves Company: Rethinking Social Initiatives by Business. Administrative Science Quarterly, 48, 268-305. http://dx.doi.org/10.2307/3556659

McGuire, J., Sundgren, A., \& Schneeweis, T. (1988). Corporate Social Responsibility and Firm Financial Performance. Academy of Management Journal, 31, 854-872. http://dx.doi.org/10.2307/256342

McWilliams, A., \& Siegel, D. (2000). Corporate Social Responsibility and Financial Performance: Correlation or $\begin{array}{llll}\text { Misspecification? Strategic } & \text { Management }\end{array}$ http://dx.doi.org/10.1002/(SICI)1097-0266(200005)21:5<603::AID-SMJ101>3.0.CO;2-3

McWilliams, A., \& Siegel, D. (2001). Corporate Social Responsibility: A theory of the Firm Perspective. Academy of Management Review, 26, 117-127.

Mishra, S., \& Damodar, S. (2010). Does Corporate Social Responsibility Influence Firm Performance of Indian Companies? Journal of Business Ethics, 95, 571-601. http://dx.doi.org/10.1007/s10551-010-0441-1

Moore, G. (2001). Corporate Social and Financial Performance: An Investigation in the U.K. Supermarket Industry. Journal of Business Ethics, 34, 299-315. http://dx.doi.org/10.1023/A:1012537016969

Moskowitz, M. R. (1972). Choosing Socially Responsible Stocks. Business and Society Review, 1, 71-75.

Newgren, K., Rasher, A., LaRoe, M., \& Szabo, M. (1985). Environmental Assessment and Corporate Performance: A Longitudinal Analysis Using Market-Deter-mined Performance Measures. In L. E. Preston (Ed.), Research in Corporate Social Performance and Policy (Vol. 7, pp. 153-164).

Orlitzky, M., Schmidt, F. L., \& Rynes, S. L. (2003). Corporate Social and Financial Performance: A Meta-Analysis. Organization Studies, 24, 403-441. http://dx.doi.org/10.1177/0170840603024003910

Oswald, S. L., \& Jahera, Jr. (1991). The Influence of Ownership on Performance: An Empirical Study. Strategic Management Journal, 12, 218-228. http://dx.doi.org/10.1002/smj.4250120407

Pava, M. L., \& Krausz, J. (1996). The Association between Corporate Social Responsibility and Financial Performance: The Paradox of Social Cost. Journal of Business Ethics, 15, 321-357. http://dx.doi.org/10.1007/BF00382958

Preston, L. E., \& O’Bannon, P. (1997). The Corporate Social-Financial Performance Relationship. Business and Society, 36, 419-429. http://dx.doi.org/10.1177/000765039703600406

Richardson, A. J., Welker, M., \& Hutchinson, I. R. (1999). Managing Capital Market Reactions to Corporate Social Responsibility. International Journal of Management Reviews, 1, 17-43. http://dx.doi.org/10.1111/1468-2370.00003

Robinson, J. P., \& Levy, M. R. (1996). News Media Use and the Informed Public: A 1990s update. Journal of Communication, 46, 129-135. http://dx.doi.org/10.1111/j.1460-2466.1996.tb01478.x

Roman, R. M., Hayibor, S., \& Agle, B. R. (1999). The Relationship between Financial and Social Performance: Repainting a Portrait. Business and Society, 38, 109-125. http://dx.doi.org/10.1177/000765039903800105

Rosenbaum, P., \& Rubin, D. (1983). The Central Role of the Propensity Score in Observational Studies for Causal Effects. Biometrika, 70, 41-55. http://dx.doi.org/10.1093/biomet/70.1.41

Rosenbaum, P., \& Rubin, D. (1985a). Constructing a Control Group Using Multivariate Matched Sampling Methods that Incorporate the Propensity. American Statistician, 39, 33-38.

Rosenbaum, P., \& Rubin, D. (1985b). The Bias Due to Incomplete Matching. Biometrics, 41, 103-116. http://dx.doi.org/10.2307/2530647

Rowley, T., \& Berman, S. (2000). A Brand New Brand of Corporate Social Performance. Business and Society, 39, 397-418. http://dx.doi.org/10.1177/000765030003900404

Rubin, D. B. (1973a). Matching to Remove Bias in Observational Studies. Biometrics, 29, 159-184. http://dx.doi.org/10.2307/2529684

Rubin, D. B. (1973a). The Use of Matching and Regression Adjustment to Remove Bias in Observational Studies. Biometrics, 29, 185-203. http://dx.doi.org/10.2307/2529685

Russo, M. V., \& Fouts, P. A. (1997). A Resource-Based Perspective on Corporate Environmental Performance and Profitability. Academy of Management Journal, 40, 534-559. http://dx.doi.org/10.2307/257052 
Schuler, D. A., \& Cording, M. (2006). A Corporate Social Performance-Corporate Financial Performance Behavioral Model for Consumers. Academy of Management Review, 31, 540-558. http://dx.doi.org/10.5465/AMR.2006.21318916

Shen, C. H., \& Chang, Y. (2009). Ambition versus Conscience, does Corporate Social Responsibility Pay off?-The Application of Matching Methods. Journal of Business Ethics, 88, 133-153. http://dx.doi.org/10.1007/s10551-008-9826-9

Spicer, B. H. (1978). Investors, Corporate Social Performance and Information Disclosure: An Empirical Study. Accounting Review, 53, 94-111.

Surroca, J., Tribo, J. A., \& Waddock, S. (2010). Corporate social responsibility and Financial Performance: The Role of Intangible Resources. Strategic Management Journal, 31, 463-490. http://dx.doi.org/10.1002/smj.820

Tsoutsourz, M. (2004). Corporate Social Responsibility and Financial Performance. Applied Financial Project, Berkeley, California.

Ullmann, A. (1985). Data in Search of a Theory: A Critical Examination of the Relationship among Social Performance, Social Disclosure, and Economic Performance. Academy of Management Review, 10, 540-577.

Vance, S. (1975). Are Socially Responsible Firms Good Investment Risks? Management Review, 64, 18-24.

Vance, S. (1995). Inside or Outside Directors: Is There Really a Difference. Across The Board, 15-17.

Waddock, S., \& Graves, S. (1997). The Corporate Social Performance-Financial Performance Link. Strategic $\begin{array}{lll}\text { Management Journal, 303-319. } & \text { 18, }\end{array}$ http://dx.doi.org/10.1002/(SICI)1097-0266(199704)18:4<303::AID-SMJ869>3.0.CO;2-G

Walley, N., \& Whitehead, B. (1994). It's Not Easy being Green. Harvard Business Review, 72, $2-7$.

Wokutch, R. E., \& McKinney, E. W. (1991). Behavioral and Perceptual Measures of Corporate Social Performance. In J. E. Post (Ed.), Research in Corporate Social Performance and Policy (Vol. 12, pp. 309-330). Greenwich, CT: JAI Press.

Wood, D. J., \& Jones, R. E. (1995). Stakeholder Mismatching: A Theoretical Problem in Empirical Research on Corporate Social Performance. International Journal of Organizational Analysis, 3, 229-267. http://dx.doi.org/10.1108/eb028831

Yang, F. J., Lin, C. W., \& Chang, Y. N. (2010). The Linkage between Corporate Social Performance and Corporate Financial Performance. African Journal of Business Management, 4, 406-413.

Yermack, D. (1996). Higher Market Valuation of Companies with a Small Board of Directors. Journal of Financial Economics, 40, 185-211. http://dx.doi.org/10.1016/0304-405X(95)00844-5

Ziegler, A., Rennings, K., \& Schröder, M. (2002). The Effect of Environmental and Social Performance on the Shareholder Value of European Stock Corporations. Working Paper. Centre for European Economic Research.

\section{Copyrights}

Copyright for this article is retained by the author(s), with first publication rights granted to the journal.

This is an open-access article distributed under the terms and conditions of the Creative Commons Attribution license (http://creativecommons.org/licenses/by/3.0/). 